\section{A review of Cushing's disease treatment by the Department of Neuroendocrinology of the Brazilian Society of Endocrinology and Metabolism}

Márcio Carlos Machado', Maria Candida Barisson Vilares Fragoso', Ayrton Custódio Moreira ${ }^{2}$, César Luiz Boguszewski ${ }^{3}$, Leonardo Vieira Neto ${ }^{4}$, Luciana A. Naves ${ }^{5}$, Lucio Vilar', Luiz Antônio de Araújo7, Nina Rosa Castro Musolino ${ }^{8}$, Paulo Augusto C. Miranda", Mauro A. Czepielewski ${ }^{10}$, Monica R. Gadelha ${ }^{4}$, Marcello Delano Bronstein', Antônio Ribeiro-Oliveira Jr. ${ }^{11}$

\begin{abstract}
The treatment objectives for a patient with Cushing's disease (CD) are remission of hypercortisolism, adequate management of co-morbidities, restoration of the hypothalamic-pituitary-adrenal axis, preservation of fertility and pituitary function, and improvement of visual defects in cases of macroadenomas with suprasellar extension. Transsphenoidal pituitary surgery is the main treatment option for the majority of cases, even in macroadenomas with low probability of remission. In cases of surgical failure, another subsequent pituitary surgery might be indicated in cases with persistent tumor imaging at post surgical magnetic resonance imaging (MRI) and/or pathology analysis of adrenocorticotropic hormone-positive $(\mathrm{ACTH}+)$ positive pituitary adenoma in the first procedure. Medical treatment, radiotherapy and adrenalectomy are the other options when transsphenoidal pituitary surgery fails. There are several options of medical treatment, although cabergoline and ketoconazole are the most commonly used alone or in combination. Novel treatments are also addressed in this review. Different therapeutic approaches are frequently needed on an individual basis, both before and, particularly, after surgery, and they should be individualized. The objective of the present review is to provide the necessary information to achieve a more effective treatment for $\mathrm{CD}$. It is recommended that patients with $\mathrm{CD}$ be followed at tertiary care centers with experience in treating this condition. Arch Endocrinol Metab. 2018;62(1):87-105
\end{abstract}

Keywords

Cushing's disease; Cushing's syndrome; treatment
1 Unidade de Neuroendocrinologia, Serviço de Endocrinologia e Metabologia, Hospital das Clínicas da Faculdade de Medicina da Universidade de São Paulo (HCFMUSP), São Paulo, SP, Brasil

Divisão de Endocrinologia

Metabologia, Faculdade de Medicina de Ribeirão Preto, Universidade de São Paulo (FMRPUSP), Ribeirão Preto, SP, Brasil

${ }^{3}$ Serviço de Endocrinologia e Metabologia (SEMPR), Hospital de Clínicas, Universidade Federal do

Paraná (UFPR), Curitiba, PR, Brasil

${ }^{4}$ Serviço de Endocrinologia,

Hospital Universitário Clementino

Fraga Filho, Universidade Federal

do Rio de Janeiro (HUCFF-UFRJ),

Rio de Janeiro, RJ, Brasil

${ }^{5}$ Serviço de Endocrinologia,

Hospital Universitário de Brasília, Universidade de Brasília (UnB), Brasília, DF, Brasil

${ }^{6}$ Serviço de Endocrinologia,

Hospital de Clínicas, Universidade

Federal de Pernambuco

(UFPE), Recife, PE Brasil

${ }^{7}$ Endoville, Joinville, SC, Brasil

${ }^{8}$ Divisão de Neurocirurgia

Funcional, Hospital das Clínicas

da Faculdade de Medicina da

Universidade de São Paulo

(HCFMUSP), São Paulo, SP, Brasil

${ }^{9}$ Serviço de Endocrinologia,

Santa Casa de Belo Horizonte

Belo Horizonte, MG, Brasil

${ }^{10}$ Servico de Endocrinologia,

Hospital de Clínicas de Porto

Alegre, Faculdade de Medicina

da Universidade Federal do

Rio Grande do Sul (UFRGS)

Porto Alegre, RS, Brasil

${ }^{11}$ Serviço de Endocrinologia

Hospital de Clínicas, Universidade

Federal de Minas Gerais (UFMG),

Belo Horizonte, MG, Brasil

Correspondence to:

Antônio Ribeiro-Oliveira Jr.

Av. Alfredo Balena, 110

Serviço de Endocrinologia,

Hospital de Clínicas, Universidade

Federal de Minas Gerais,

30130-100 - Belo Horizonte, MG, Brasil

antoniorojr@gmail.com

Received on Feb/07/2017

Accepted on Oct/02/2017

DOI: $10.20945 / 2359-3997000000014$

\section{INTRODUCTION}

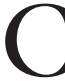
ushing's syndrome is associated with a high mortality risk (1-10). A meta-analysis has found a standardized mortality ratio (SMR) of 2.22 (range, $1.45-3.41$; confidence interval, CI, 95\%) in patients with Cushing's syndrome compared to the general population (7). The major causes of mortality in these patients are cardiovascular diseases (ischemic heart disease and cerebrovascular diseases), diabetes mellitus (secondary to hypercortisolism), and infections (due to immunosuppression).
Clearly, the mortality rate is influenced by the disease activity. The SMR is higher in patients with persistent disease when compared to patients in clinical remission of the hypercortisolism: 5.50 (range, $2.69-11.26$ ) vs. 1.20 (range, $0.45-3.18$ ), respectively $(7)$.

Nevertheless, even after the resolution of hypercortisolism, there may not be a complete reversal of cardiovascular risk factors or, alternatively, a complete reversal may take more than 5 to 6 years to occur $(8,11,12)$. In addition, patients with active Cushing's disease (CD) present with poorer quality of 
life and lower scores might persist even after surgical remission (13).

One factor contributing to the onset and progress of associated co-morbidities is the time spent since the recognition of the disease, its diagnostic confirmation (involving complex and expensive laboratoty and imaging studies), and correct definition of the etiology (1,14-17). Accordingly, a recent study showed increased mortality in patients with longer exposure to hypercortisolism (8).

Thus, to improve the prognosis of patients with Cushing's syndrome and to help reverse morbidities, it is important to identify the disease and to achieve eucortisolism as soon as possible.

The objective of the present review is to provide the necessary information to achieve a more effective treatment of CD. The specific therapeutic approach of the several co-morbidities associated with $\mathrm{CD}$ is beyond the scope of this review. The present manuscript highlights the importance of centers of excellence with a highly experienced multidisciplinary team for longterm follow-up of these patients

\section{TREATMENT}

The goals of the treatment of CD are as follows: (i) remission of hypercortisolism, (ii) adequate management of co-morbidities and cardiovascular risk factors, (iii) restoration of the hypothalamicpituitary-adrenal axis, (iv) preservation of fertility and maintenance of pituitary function and (v) improvement of visual defects in cases of macroadenomas with suprasellar extension. However, it is common that one or more objectives need to be sacrificed to achieve remission in a patient (18).

Although surgical treatment generally results in high remission rates at short term in series from specialized centers $(\sim 70-80 \%)$, recurrence is observed in a substantial proportion of patients who then need other therapies to control hypercortisolism.

\section{Surgical treatment}

Despite advances in drug treatment and progress in other therapeutic modalities, such as stereotactic radiotherapy, surgical treatment is still the principal definitive treatment for CD (19).

Some recommendations regarding the preoperative management of patients with $\mathrm{CD}$ should be taken into account. Due to a higher risk of cardiovascular complications, such as coronary heart disease, it is important to conduct a careful cardiac assessment of these patients. However, the risk stratification does not differ from that in individuals without Cushing's syndrome. There is also increased risk of thromboembolic events, both pre- and postoperatively (PO) (20-25). Thus, the analysis of coagulation factors is very important, although there are no formal guidelines to define which factors should be analyzed in addition to those traditionally considered (i.e., thrombin time, prothrombin time, thromboplastin activated time, platelets) or which coagulation protocol should be recommended before and after surgery (26). In patients treated with antiplatelet drugs (to prevent ischemic events), antiplatelet therapy should be withdrawn at least seven days before surgery.

Usually, drug treatment for hypercortisolism is unnecessary during the preoperative period. Nevertheless, in some cases, it is necessary to initiate a specific medical treatment during the preoperative period, for instance, in patients with more severe disease and increased preoperative risk and when surgical treatment can not be immediately performed. The most commonly used approach is therapy with adrenal steroidogenesis inhibitors, particularly ketoconazole, which has a shorter half-life than the dopaminergic agonist cabergoline, which acts on corticotroph tumors and causes less interference with cortisol measurements during the PO period (27).

Many factors influence transsphenoidal surgery remission rates, including characteristics of the pituitary adenoma (e.g., tumor size, location, extension, aggressiveness, histological type and radiological identification), surgical procedure (e.g., the quality of the equipment and surgical technique), variability of the remission criteria used, and, particularly, the surgeon (e.g., experience, surgical identification of the tumor) (28).

All factors mentioned above contribute to the wide range of $\mathrm{PO}$ remission rates reported on by numerous case studies. In general, the mean remission rate ranges from $70 \%$ to $90 \%$ in several reviews $(19,27,29,30)$. However, within the same case series, the remission rate may vary, depending on the subset of the patient analyzed, e.g., whether patients had a micro or a macroadenoma, whether tumor was identified on preoperative pituitary magnetic resonance imaging (MRI) or during surgery; and whether patients had been previously submitted to bilateral and simultaneous 
petrosal sinus sampling (BIPSS). Importantly, recurrence may occur several years later.

In cases of macroadenoma $(\geq 10 \mathrm{~mm})$, the remission rate ranges from $50 \%$ to $70 \%(27)$ and is generally lower than the microadenoma remission rate (19). These percentages can vary depending on the size and, particularly, the degree of invasion of the adenoma into the adjacent tissues. A study performed on a small sample $(\mathrm{n}=40)$ identified tumor size as the main factor responsible for post surgical remission rate. The authors observed remission rates of $84 \%$ for microadenomas $(21 / 25), 92 \%$ for macroadenomas ( $11 / 12$; mean of 15 $\mathrm{mm}$; only 2 with invasion) and no remission for patients without visible tumor during surgery $(\mathrm{n}=3)(31)$.

The remission rate in patients submitted to BIPSS is also lower than that observed in visible microadenomas on MRI and ranges from $50 \%$ to $70 \%(27,32)$. Interestingly, a study that specifically assessed remission in these cases did not show any difference between positive and negative MRI findings (33). In this subset, the main factor influencing remission rate was the intraoperative identification of the tumor.

Other predictive factors of a better surgical outcome include absence of invasion of the duramater or cavernous sinuses, histological confirmation of adrenocorticotropic hormone-positive (ACTH+) adenoma, low serum cortisol levels during the PO period, and prolonged secondary adrenal insufficiency (> 12 months) (27).

In pediatric patients, the number of reported cases is lower, but remission rates are similar or slightly increased in some cases, ranging from $83 \%$ to $98 \%$ $(34,35)$. A recent study identified histopathology with an ACTH+ pituitary adenoma and no invasion as early predictors of remission in children. Young age, smaller tumors and no invasion of duramater or cavernous sinuses were predictive of long-term remission (35).

Almost all patients undergo pituitary surgery via transsphenoidal endonasal approach, including those with macroadenoma $(29,30)$. Craniotomies are the exception and are indicated in rare selected cases. The most studied is the microscopic technique, but the endoscopic approach has been increasingly used in the last decade. The remission rate is similar for both techniques, particularly in the case of microadenomas (30,36-40). For macroadenomas and invasive tumors, the endoscopic technique has a potential advantage in offering a greater angular field of view, and therefore visualizing and removing tumors impinging the cavernous sinus or extending beyond the sellar boundaries. Other techniques that can improve intraoperative tumoral localization, such as ultrasonography, neuronavigation, rapid pathological and/or hormonal analysis and intraoperative MRI, are not available in most centers and therefore their usefulness cannot be properly evaluated so far.

Adenomectomy is the most performed surgery, although exploration of the entire glandisjustified in most cases. In patients with no identified tumor, an ipsilateral hemi-hypophysectomy (partial hypophysectomy) is usually performed in the side suggested by BIPSS with lower remission rates. Total hypophysectomy is rarely justified due to a limited remission rate in such cases and expected hypopituitarism (27).

Pituitary surgery has a low mortality rate $(0 \%$ to $\leq 1.5 \%),(29,41)$ comparable to the outcomes observed in simpler surgical procedures. The most common complications are endocrine: transient diabetes insipidus in $3 \%$ to $9 \%$ of patients (polyuria and/or hypernatremia), hyponatremia that can result from secondary adrenal insufficiency, particularly in patients not taking glucocorticoids, or syndrome of inappropriate antidiuretic hormone secretion (SIADH), and other pituitary deficiencies (growth hormone deficiency, hypogonadotropic hypogonadism, central hypothyroidism). Other complications include cerebrospinal fluid fistula $(<8 \%)$, bleeding or hematomas (range, 1-6\%), epistaxis, infections (particularly sinusitis), and thromboembolic events (29). Due to the risk of thromboembolic events, it is recommended to perform active prophylaxis, including pneumatic compression of the lower limbs, lowmolecular-weight heparin treatment as soon as possible (24h after surgery), and early mobilization during the hospital stay. However, there is no current specific anticoagulation protocol for Cushing's disease. The rates of complications derived from microsurgery and endoscopic techniques are similar.

\section{Criteria for remission, glucocorticoid replacement therapy, and prediction of recurrence risk}

Several clinical and laboratory criteria are used to define PO remission, but there is no consensus or ideal method that guarantees a recurrence-free followup period (29). However, a patient who develops adrenal insufficiency with very low serum cortisol levels $(<2 \mathrm{mg} / \mathrm{dL})$ and requires glucocorticoid 
replacement therapy clearly exhibits PO remission. However, these "rigid" laboratory criteria are not found in up to $20 \%$ of patients who show long-term remission and exhibit "normal" PO cortisol levels (42). Other factors used to define post surgical remissions are reversal of hypercortisolism, need of glucocorticoid replacement therapy and normalization of cortisol parameters, particularly urinary free cortisol (UFC) lasting at least 6 months after surgery.

Adrenal insufficiency is not clear in all cases, particularly when early glucocorticoid replacement therapy is routinely performed or in previously treated patients who undergo surgery and who exhibit eucortisolism. The symptoms that indicate adrenal insufficiency are asthenia, appetite loss, nausea, skin peeling, joint and muscle pain, weight loss, low blood pressure and/or postural hypotension. Mild hyperthermia, a transient increase in TSH levels, and hyponatremia might also occur. Although ACTH also stimulates aldosterone secretion, it should be highlighted that severe hypotension and hyperkalemia are not common due to the integrity of the reninangiotensin-aldosterone system.

The most studied and utilized laboratory parameter is serum cortisol. In a recent guideline, a cortisol level $<5 \mu \mathrm{g} / \mathrm{dL}$ in the first PO week was stated as indicative of remission (19). Other authors have attempted to identify a more accurate "ideal" cortisol level (43). However, it is known that even undetectable levels of serum cortisol are not a guarantee of long-term remission (44), and an important study observed recurrence in $20 \%$ of patients at 5 years, even among those with cortisol levels $<2 \mu \mathrm{g} / \mathrm{dL}$ (45). Thus, more important than determining an "ideal value" is to understand that there are different levels of recurrence associated with serum cortisol values, as follows: $<2$, low risk; $2-5$, intermediate risk; > $5 \mu \mathrm{g} /$ $\mathrm{dL}$, high risk (46). Another important finding is that $5.6 \%$ of patients present a gradual decline in cortisol levels after the first week ("late remission") (47). For this reason, other cortisol samples must be collected, particularly during the first PO month. The two most cited explanations for this fact are the persistence of cortisol secretion due to chronically stimulated adrenal glands and the subsequent post surgical necrosis of corticotropic tumor cells. Interestingly, one study has shown increased long-term recurrence in patients from this late remission subgroup (47).

A very important factor for the analysis of serum cortisol levels in the PO period is glucocorticoid replacement therapy. Generally, two replacement strategies have been used and they do not include glucocorticoids during anesthetic induction. In one strategy, routine replacement therapy is not performed during the immediate PO period and in the initial days. Despite the short half-life of cortisol (range, 50-70 minutes) and intense reduction of its serum concentration after a successful adenoma removal, the patient does not usually show adrenal insufficiency too early $-24-48$ hours - after surgery (48-50). Thus, the measurement of morning cortisol or a $6 / 6$-hour curve starting in the immediate PO period is performed during the first days, and glucocorticoid replacement is initiated only after suggestive symptoms of adrenal insufficiency (with measurement being performed immediately before) and/or when low levels of cortisol are detected $(<5 \mu \mathrm{g} / \mathrm{dL})$. Endocrinologists should closely assess the patient, if possible, until replacement is initiated. In this strategy, one advantage is that serum cortisol measurements are not influenced by exogenous corticosteroids. The second strategy consists of initiating routine glucocorticoid replacement therapy during the immediate PO period, preferably with short half-life corticoids, such as hydrocortisone (immediate PO, 25-50 mg intravenously three times per day), followed by oral hydrocortisone (from the $1^{\text {st }} \mathrm{PO}$ day forward: $20 \mathrm{mg}$ early in the morning, $10 \mathrm{mg}$ at $2 \mathrm{PM})$. In this way, serum cortisol measurements are performed only in the morning from 8 to 9 AM on any given day, under fasting condition, 18 to 24 hours after the last dose. The main advantages of this strategy are (i) easy applicability; (ii) patient safety; (iii) a lower incidence of adrenal insufficiency symptoms, although relative adrenal insufficiency can still occur with replacement therapy; (iv) reduced suppression of the hypothalamic-pituitary-adrenal axis (good for the pediatric population) compared with longer half-life drugs, such as prednisone or dexamethasone; and (v) easy measurement of serum cortisol, which allows the physician to observe the progressive increase of serum cortisol levels along with the recovery of the axis, which occurs 6 to 18 months PO.

However, although it is the most used glucocorticoid in this clinical setting, hydrocortisone is commercialized in Brazil in just one tertiary center (hydrocortisone, 20 and $5 \mathrm{mg}$ tablets). The advantage of using dexamethasone (dose: $0.25-1 \mathrm{mg}$ once daily; tablets with $0.5,0.75$ and $4 \mathrm{mg}$ ) is that it does not usually interfere with the serum and urine cortisol measurement, and it has been 
used in some centers (29). However, due to its longer half-life, even when used at low doses, it is not possible to exclude the suppression of the axis, potentially leading to underestimated cortisol levels. The only advantage of prednisone (dose: 2.5 - $5 \mathrm{mg}$ once daily; tablets, 5 and $20 \mathrm{mg}$ ) is the diffuse availability of the product; however, this drug can cause interference with the cortisol measurement and may suppress the axis with chronic use, although the risk of suppressing the axis is lower when compared to dexamethasone. Prednisone should be withdrawn at least $48 \mathrm{~h}$ before serum and/urine cortisol measurements, leading to an increased need of observation for the risk of adrenal insufficiency. Recently, another form of oral dualrelease hydrocortisone has been studied in patients with adrenal insufficiency (51). However, there is no data on advantages of these formulations in this subgroup of PO patients with $\mathrm{CD}$ in order to normalize the hypothalamic pituitary adrenal axis.

In addition to serum cortisol, other laboratory criteria have been used, albeit infrequently, to define short-term remission (40). Among these criteria are lower than normal UFC (47), lower than normal plasma ACTH (52) and cortisol suppression after a low dose of dexamethasone (15).

Among these parameters, ACTH measurement is currently the most studied and is primarily used to predict the risk of long-term recurrence $(49,53)$. A study that analyzed patients in initial $\mathrm{PO}$ remission (serum cortisol $<3 \mu \mathrm{g} / \mathrm{dL}$ ) showed lower PO ACTH in patients with long-term remission compared to those with recurrent disease (11.9 vs. $34.3 \mathrm{pg} / \mathrm{mL}, p<$ 0.0001 , respectively) (49).

One study investigated late-night salivary cortisol and found this parameter to be more accurate in predicting $\mathrm{PO}$ remission in comparison to serum cortisol and UFC (54). Late-night salivary cortisol was measured starting from 6 months PO. Further studies are necessary to show the utility of this method in assessing initial remission. However, there are studies showing a good utility of this method for earlier diagnosis of recurrence, even before the UFC $(55,56)$.

Other methods are used to predict the risk of long-term recurrence. Primary among these methods are measurements of ACTH or cortisol following administration of corticotropin-releasing hormone (CRH) (46), metyrapone, thyrotropin-releasing hormone (TRH), luteinizing hormone-releasing hormone (LHRH), loperamide and desmopressin.
The rational of these tests derives from the incapacity of normal corticotropes, suppressed by hypercortisolism, to secrete ACTH. In this way, early PO responses suggest the presence of residual tumor cells and, consequently, an increased risk of recurrence. The response to desmopressin is the most used test, with several studies showing similar results (57-64). One of the major problems with this test is the definition of ACTH and cortisol responses after desmopressin administration in the PO period. Several authors have used criteria similar to those used in the preoperative period (i.e., serum cortisol increased by $>20 \%$ and ACTH increased by $>30 \%$ to $50 \%)(57-61,63,64)$. These definitions, however, may overestimate any observed increase; for example, a change in serum cortisol from 1 to $2 \mu \mathrm{g} / \mathrm{dL}$ could correspond to an increase of $100 \%$. A previous study assessed the risk of recurrence if the variation of serum cortisol is $>7 \mu \mathrm{g} / \mathrm{dL}$ (variation $(\Delta)$ : peak minus time 0$)$ after IV desmopressin $10 \mu \mathrm{g}$ administration approximately 2 weeks PO. This method had a specificity of $100 \%$ and a sensitivity of $33 \%$. It should be noted that in this previous study, only patients with low serum cortisol (< $6 \mu \mathrm{g} / \mathrm{dL}$ approximately 6 days PO) were subjected to the test, excluding patients with a risk of recurrence due to increased PO cortisol levels (62). Another factor to be kept in mind as associated to lower risk of recurrence is the higher length of postoperative glucocorticoid replacement, such as more than 12 months (41).

\section{Surgery following initial surgical failure}

After an initial surgical failure, the clinical case must be entirely reviewed. A diagnosis of CD should be confirmed by histopathological examination of the pituitary adenoma, which should be ACTH-positive on immunohistochemistry. If no adenoma has been found and the pituitary gland is reported as normal, then the diagnosis might be confirmed through $\mathrm{PO}$ remission or through the central to peripheral ACTH gradient at BIPSS. BIPSS might be performed with the sole objective of confirming a central origin not yet proven, considering that lateralization cannot be trusted to predict tumor localization. Another important issue is the description of the surgery as reported or registered by the surgeon. For example, a report of partial tumor resection due to invasion of the cavernous sinus in a macroadenoma patient limits the indication for subsequent surgery (29). The confirmation of 
pituitary adenoma is also important in deciding upon a new pituitary surgical procedure. This should be evaluated with a new pituitary MRI performed at least 3 months after transsphenoidal surgery showing a residual tumor (65). These aspects need to be carefully analyzed before referring patients for another pituitary surgical procedure, especially if the first operation was not performed by an experienced surgeon (29). The remission rate is lower than observed for the first surgery, ranging from $40 \%$ to $70 \%(27,66,67)$, a rate that is similar to that obtained with current medical treatment. In addition, it is important to highlight that the rate of complications, including cerebrospinal fluid fistula and hypopituitarism, is higher when compared to the first surgery.

Some authors recommend early re-operation at 3 to 15 days after initial surgical failure, defined by serum cortisol $>2 \mu \mathrm{g} / \mathrm{dL}(53,68-70)$. However, as late remission can occur in $5.6 \%$ of patients 30 to 50 days after the initial surgery (47), this strategy is not commonly used.

\section{Medical treatment}

Medical treatment can be classified as primary or secondary. Primary therapy is used to lower cortisolemia and improve preoperative clinical conditions, or in cases of surgical contraindication or refusal, or before other definitive approaches. Secondary treatment after surgical failure is much more common, and is indicated for patients with relapse and no indication for a new surgery, as well as in patients who undergo pituitary radiotherapy. The drugs are classically divided into three classes: a) acting on the ACTH-secreting tumor, b) adrenal steroidogenesis inhibitors, and c) cortisol receptor antagonists. The first two classes comprise several drugs, some of which are currently in use and several others are not available or are under development. The limited number and availability of these drugs reflect the difficulty of controlling cortisol levels in CD patients. No ideal treatment is available, as reviewed in several recent articles (18,22,23,71-80).

\section{Drugs acting on the corticotropic tumor \\ Cabergoline}

Due to the very frequent expression of dopaminergic subtype 2 receptors (DRD2) on the surface of tumor cells in several types of pituitary adenomas, dopamine agonists, particularly cabergoline, have been used to treat prolactinomas (first option), acromegaly (adjuvant), clinically non-functioning adenomas and CD (adjuvant).

A study on corticotropic tumors elegantly demonstrated the expression of DRD2 in more than $80 \%$ of tumor samples, which exhibit binding affinity and in vitro inhibition of ACTH secretion in response to dopamine agonists $(50)$.

For the treatment of $\mathrm{CD}$, bromocriptine was initially used with limited efficacy and common side effects due to the need of high doses (range, $3.75-$ $30 \mathrm{mg}$ ). Thus, the use of bromocriptine is no longer justified. Cabergoline, a better-tolerated and more potent and specific DRD2 receptor agonist, has been assessed for efficacy in some studies (50,81-85). UFC normalization, the primary endpoint for most studies, was observed in $25-40 \%$ of the 72 patients analyzed (4 studies with at least 10 cases), with mean dose of $3 \mathrm{mg} /$ week (range, $1-7$ ) and an average treatment period of 18 months (range, $3-60)(50,81-83)$. No long-term response predictor has been identified and there have been few cases studying the correlation between the in vivo response and DRD2 receptor tumor expression (50). The efficacy of cabergoline declines with increasing treatment duration, an effect that is primarily due to tachyphylaxis, which occurs due to unknown mechanisms and is observed in $18-30 \%$ of cases $(81,82)$, even with prolonged use ( $1-5$ years) $(81,82)$. Cabergoline therapy is usually initiated at 1 $\mathrm{mg} /$ week $(0.5 \mathrm{mg}$ twice per week, at night; tablets, $0.5 \mathrm{mg}$ ), with a monthly increase of $1 \mathrm{mg}$ if UFC normalization does not occur. One study defined unresponsiveness as a reduction in UFC lower than 25\% after 3 months of treatment with increasing doses (81). A reduction in tumor size/volume was poorly assessed in previous studies. A reduction of at least $25 \%$ of the tumor size occurred in $50 \%$ of cases in one study (81), although case reports have demonstrated significant reductions $(86,87)$. There is a recommendation for monitoring cardiac valves by echocardiogram during cronic use of cabergoline due to potential risk of thickening described with larger doses of cabergoline in Parkinson's patients (88). However, there are no data on echocardiographic changes after prolonged use in Cushing's patients. Finally, although studies have shown the effectiveness of cabergoline in a subset of patients with CD, its use is off-label, and it is not approved for CD treatment in Brazil. 


\section{Pasireotide}

The first-generation somatostatin analogues octreotide and lanreotide, traditionally used to treat patients with acromegaly, are not indicated for the treatment of CD due to the low expression of the subtype 2 somatostatin receptor (SSTR2) as a consequence of down regulation by hipercortisolism in corticotrope tumors $(89,90)$. The development of new somatostatin analogues with a different affinity profile to SSTR subtypes has opened new therapeutic possibilities. Pasireotide is the first specific drug approved for the treatment of CD in Europe, USA and recently in Brazil (ampules for subcutaneous use: 300, 600 and $900 \mathrm{mg}$ ). In comparison to first-generation somatostatin analogues, pasireotide has increased affinity to SSTRl ( $>30$ times), SSTR3 (> 3 times) and, particularly, SSTR5 (> 40 times) (27), which is the most expressed receptor in tumor corticotropes (91). This new analogue has been tested both in vitro $(92,93)$ and in vivo studies (94). The core study employed in the pasireotide approval was published in 2012 (95). This was a prospective, multicenter, double-blind study on the use of pasireotide in patients with persistent or recurrent CD or naïve patients who could not undergo surgical treatment. Two doses were tested (600 or $900 \mu \mathrm{g}$ SC twice per day) for 12 months, and a total of 162 patients were assessed. A significant UFC reduction (at least $>50 \%$, primary endpoint) was observed in $49 \%$ of patients at 6 months, with UFC normalization in $28.8 \%$ of patients who were treated with $900 \mu \mathrm{g}$ of pasireotide, a response that was maintained up to 12 months with no relapses during this period. A subsequent extension study showed a similar and sustained response after 24 months (96) and even in longer studies up to 72 months $(73,91,97)$.

The therapeutic response to pasireotide depends on the intensity of hypercortisolism. Complete response was noted in $50 \%$ of patients with baseline UFC up to twice the upper limit versus $8 \%$ in those with baseline UFC $>5$ times the upper limit (95). In addition, an early response at 2 to 3 months predicted a sustained response at 12 months. Parameters such as weight, blood pressure, lipid profile and quality of life improved in patients with reduced UFC, even when normalization was not achieved. An analysis of tumor volume was performed in a subset of patients and showed a reduction of $43.8 \%$ (compared to initial volume) at 12 months in patients who are treated with
$900 \mathrm{mg}$. Side effects were very common and similar to those of other somatostatin analogues (i.e., diarrhea, nausea, cholelithiasis, mild increase of liver enzymes, bradycardia, and others). At 12 months, $73 \%$ of patients experienced adverse events related to hyperglycemia, but most of the events were considered mild to moderate (95). These events are due to a concomitant inhibition of insulin, glucagon-like peptide l (GLPl) and glucose-dependent insulinotropic polypeptide (GIP), as well as to only a slight inhibition of glucagon $(43,98)$. Thus, in addition to metformin (usually used in CD patients), dipeptidyl peptidase 4 (DPP4) inhibitors or GLPl analogues should be the first options to treat hyperglycemia in this situation. Another undesired effect observed in a short-term study (80 days) was a reduction in insulin-like growth factor 1 (IGF1) levels to lower than normal in $>50 \%$ of patients $(99)$.

\section{Adrenal steroidogenesis inhibitors}

\section{Ketoconazole}

Ketoconazole is one of the most prescribed drugs for the treatment of CD, despite being used off label. This compound is an imidazole antifungal drug that reversibly inhibits adrenal steroidogenesis through the action of several enzymes (i.e., cholesterol desmolase, $17 \alpha \mathrm{OH}$ and $11 \beta$-hydroxylase). Ketoconazole also inhibits androgen production resulting in hypogonadism in men (gynecomastia, decreased libido and erectile dysfunction); in women, in contrast, it might improve hyperandrogenism.

Two studies published in 2008 and 2014 provided the best assessment of ketoconazole use in CD $(100,101)$. In the oldest study, 38 cases were analyzed and 6 series were reviewed, totalizing 99 patients. The series included patients who had undergone previous radiotherapy (102), small numbers of cases ( $6-8$ cases) (103-107), or short-term follow-ups (range, $15-30$ days) (104-107). Of the 38 patients, $51.5 \%$ achieved a normal UFC with a mean treatment period of 22 months $(6-72)$ and a mean dose of $529 \mathrm{mg} /$ day (range, 200 $-1000 \mathrm{mg}$ ). Five patients (13\%) interrupted treatment due to side effects (nausea, diarrhea, and increased levels of transaminases by five-fold in one patient) during the first week. A few cases without visible tumors were primarily treated with ketoconazole. Onethird of these patients $(5 / 15)$ showed visible lesions during follow-up (after 12 - 30 months) and were then submitted to surgery (101). No tumor progression 
occurred in patients who already had a lesion visible by MRI, although the study did not report the proportion of micro- and macroadenomas. Similar results were found in the more recent multicenter retrospective study with a larger group of 200 patients. Normal UFC was observed in $49.3 \%$ of patients with mean dose of $600 \mathrm{mg}$ /day during mean time of observation of 24 months (100).

Another study showed similar control of disease activity in $9 / 17$ patients (53\%) during the preoperative period of patients with Cushing's syndrome (pituitary or adrenal in $85 \%$ of cases) treated with $200-1000$ $\mathrm{mg} /$ day over a mean period of 4 months (108). Usually, treatment begins with $400 \mathrm{mg} /$ day $(200 \mathrm{mg}$ twice daily; tablets: $200 \mathrm{mg}$ ), with the medication not taken near meals, as an acidic $\mathrm{pH}$ is needed for absorption. Accordingly, the use of proton pump inhibitors decreases drug availability. The dose is increased monthly, up to $1200 \mathrm{mg} /$ day, to achieve UFC normalization, although it is uncommon to reach the maximum dose. Similar to cabergoline, tachyphylaxis may occur in up to $33 \%$ of patients following prolonged use of ketoconazole $(101,108)$. Mild side effects are relatively common and include headache, nausea, and rash. Another important side effect is increased levels of hepatic transaminases by as much as 3 times the upper limit. Such increase is usually asymptomatic and reversible with drug interruption or dose reduction. Thus, it is important to monitor hepatic transaminases during the first month of treatment and thereafter. Idiosyncratic severe hepatic insufficiency has been described on rare occasions $(19,109)$.

\section{Metyrapone}

Metyrapone is used to assess the sufficiency of the hypothalamic-pituitary-adrenal axis and to treat CD. A reduction of hypercortisolism is achieved by blocking adrenal steroidogenesis via the inhibition of $11 \beta$-hydroxylase. This enzyme converts 11-desoxicortisol (compound $S$ ) to cortisol, and treatment with metyrapone can result in a rebound of ACTH levels (73). Treatment usually begins at $250-500 \mathrm{mg}, 3-4$ times per day, with a maximum dose of $4-6 \mathrm{~g} /$ day (capsules, $250 \mathrm{mg}$ ). In addition, the drug acts rapidly (from hours to days). Due to ACTH rebound and a shift in the production of other steroids, metyrapone increases androgen production and commonly causes hirsutism and acne. This drug may also cause mineralocorticoid effects, such as hypertension and hypokalemia. In general, shortterm studies show control of the cortisol excess in a significant number of patients (73). A study showed control in $75 \%$ of patients treated with a mean dose of $2250 \mathrm{mg} /$ day (110). One study assessed the use of metyrapone during the preoperative period in patients with Cushing's syndrome (85\% pituitary) and showed UFC control in $26 \%$ of patients $(6 / 23)$ treated with 750 $-4500 \mathrm{mg} /$ day for an average of 4 months (108). In the larger multicenter retrospective study, normal UFC was found in $43 \%$ of Cushing's syndrome patients from all etiologies (CD, Ectopic ACTH syndrome (EAS), adrenal diseases) in a mean of 8 months ( 3 days -12 years) (111). Long-term studies with a large number of CD cases are necessary to better assess the effects of this drug. In addition, this drug is not available in Brazil. Metyrapone is currently available in USA and Europe.

\section{Etomidate}

Etomidate is an intravenous anesthetic (imidazole carboxylate derivative) that decreases cortisol levels by inhibiting $11 \beta$-hydroxylase $(112,113)$. The main advantage of etomidate is its rapid time of action, allowing reduction or normalization of serum cortisolin less than 24 hours. Thus, etomidate is useful for severe cases of Cushing's syndrome, generally patients with ectopic ACTH syndrome (EAS). Treatment is performed in hospitalized patients, especially in intensive care units, due to clinical severity and the need for close monitoring, although the dose used is usually safe and does not cause severe sedative effects. Treatment assessment is primarily performed by the measurement of serum cortisol (113), and care should be taken to avoid adrenal insufficiency. 'Block and replace' therapy with hydrocortisone IV can be used. Treatment is performed by continuous intravenous infusion and may consist of an initial bolus of $0.03 \mathrm{mg} / \mathrm{kg}$ followed by 0.1 $-0.3 \mathrm{mg} / \mathrm{kg} /$ hour (ampules, $2 \mathrm{mg} / \mathrm{mL}$ ). Intermittent use for several hours with periodic intervals has been described. A review published in 2012 including 18 studies (mostly case reports) with a total of 12 patients with $\mathrm{CD}$ found cortisol normalization in virtually all cases when used from 5 hours to 56 days (113).

\section{Mitotane}

Also known as o,p'-DDD (dichloro-diphenyl-dichloroethane), mitotane is an oral chemotherapy used to treat 
patients with adrenal carcinoma. Mitotane is considered an adrenolytic compound due to mitochondrial toxicity that causes cellular necrosis. In addition, mitotane inhibits the adrenal production of cortisol by acting on enzymes involved in steroidogenesis (i.e., 11 $\beta$-hydroxylase and cholesterol desmolase) (114). Mitotane is a lipophilic drug, has a slower mechanism of action than other inhibitors, and has a very long half-life due to storage in adipose tissue (range, 18 159 days). The established dose for the treatment of adrenal cancer is high (approximately $8-12 \mathrm{~g} /$ day), and the effective dose is verified by mitotane levels $>14-20 \mu \mathrm{g} / \mathrm{mL}$. However, for the treatment of $\mathrm{CD}$, lower, non-adrenolytic doses are prescribed, i.e., approximately $2-4 \mathrm{~g} /$ day (115), depending on the patient's profile and UFC. Usually, treatment is initiated at $500 \mathrm{mg}$ at bedtime, with doses increasing every $1-4$ weeks (according to tolerance to treatment) up to $2-3 \mathrm{~g} /$ day in fractionated doses at meals (tablets, $500 \mathrm{mg}$ ). In contrast to the effective dose for adrenal cancer treatment, there is no target mitotane concentration for CD, and UFC monitoring is the most important parameter. In one study, mitotane levels > $8.5 \mu \mathrm{g} / \mathrm{mL}$ were associated with normal UFC levels during follow-up (114). Use of mitotane is limited due to relatively common and severe side effects, such as nausea, vomiting, anorexia, rash, diarrhea, ataxia, gynecomastia, arthralgia, leukopenia, hepatotoxicity and hypercholesterolemia. In addition, mitotane may cause adrenal insufficiency, which can occasionally be underestimated due to an increase in cortisol binding globulin (CBG) levels. Due to increased corticoid metabolism, higher doses might be needed for adrenal insufficiency replacement. One study that assessed the use of mitotane in 76 patients with CD showed UFC normalization in $72 \%$ of patients with a mean treatment duration of 6.7 months (range, $5.2-8.2$; mean dose, $2.6 \pm 1.1 \mathrm{~g} /$ day) $(114)$. Similar to the ketoconazole study (101), $25 \%$ of cases without a visible pituitary tumor developed a visible lesion during follow-up, which allowed patients to undergo surgical treatment (114). Due to limited availability, difficult management and high cost, this option is rarely used in Brazil for the treatment of CD.

\section{Cortisol receptor antagonist mifepristone}

Mifepristone is an antiprogestogen that, at high doses, rapidly and competitively antagonizes the cortisol receptor, resulting in a rebound increase of ACTH and cortisol plasma levels (116). Thus, monitoring of mifepristone therapy in Cushing's syndrome should be performed using clinical and biochemical parameters such as serum glucose, and not ACTH or cortisol levels. Mifepristone was approved in 2012 in the USA to control hyperglycemia (diabetes mellitus or glucose intolerance) in patients with endogenous Cushing's syndrome (tablets, $300 \mathrm{mg}$ ). The approval was based mainly on the results of the SEISMIC trial (71), a prospective, multicenter, 24-week study of patients with endogenous Cushing's syndrome, and diabetes mellitus/glucose intolerance or isolated high blood pressures, who were unresponsive to other therapies (71). The trial involved 50 patients: 43 with $\mathrm{CD}, 4$ with EAS, and 4 with adrenal carcinoma. All of the patients received initially $300 \mathrm{mg} /$ day, and the dose was increased to 600,900 , and $1200 \mathrm{mg}$ /day every 4 weeks if clinical improvement was not observed. The primary endpoints were (i) a decrease in the area under the curve (AUC) of glucose of at least $25 \%$ on the $75 \mathrm{~g}$ oral tolerance test and (ii) a reduction by $>5 \mathrm{mmHg}$ of diastolic blood pressure. With a mean dose of $600 \mathrm{mg} /$ day, improvement in glycemia (AUC) was observed in $60 \%$ of patients (mean reduction, $36 \%$ ), and the $\mathrm{HbAlc}$ levels decreased from $7.43 \pm 1.52$ to $6.29 \pm 0.99 \%$. Diastolic blood pressure improved in $38.1 \%$ of patients. In addition, improvements were observed in weight $(-5.7 \%)$, waist circumference, and insulin sensitivity. The main side effects, primarily mild or moderate, were nausea, fatigue, headache, hypokalemia (effect of cortisol on mineralocorticoid receptor), arthralgias and endometrial thickening/menorrhagia. Others concerns about the use of mifepristone is the adrenal insufficiency not biochemically detected but amenable to be treated with high dose of dexamethasone while withholding mifepristone, and the possible risk of tumor enlargement recently published (117).

\section{Combination therapy and perspectives}

Given that the control rate is limited with the currently used drugs, especially in patients with severe Cushing's syndrome, combinations of different medications have been used as an alternative approach to control hypercortisolism (118). Combination therapy can be performed with medications from the same therapeutic class (e.g., combined use of steroidogenesis inhibitors) or from different classes (e.g., cabergoline + ketoconazole). 


\section{Combined use of adrenal steroidogenesis inhibitors}

At least two recent studies assessed the effect of the combined use of adrenal steroidogenesis inhibitors. Using ketoconazole and metyrapone (doses: 200 - $1000 \mathrm{mg}$ and $750-4500 \mathrm{mg}$, respectively) for an average of 4 months (range, $1-30$ ), one study showed control (defined as UFC, clinical parameters and morbidity normalization) in $23 \%$ of patients with Cushing's syndrome $(5 / 22)$ in the preoperative period (108). The second study assessed the effect of a triple combination of mitotane, metyrapone and ketoconazole as an alternative to adrenalectomy in 11 patients with severe ACTH-dependent Cushing's syndrome (UFC: $853-22605 \mu \mathrm{g} / 24 \mathrm{~h}$, reference 10 - 65), 4 patients with CD and 7 with EAS. Significant and rapid (24 - 48 hours) improvements in clinical and laboratory parameters were observed in all cases, with a reduction of UFC from 2737 to $50 \mu \mathrm{g} / 24 \mathrm{~h}$ (range, 18 - 298) and normalization achieved in 64\% of patients. The treatment was initiated with all three drugs simultaneously: $2250 \mathrm{mg}$ /day metyrapone, 800 $\mathrm{mg} /$ day ketoconazole, and $3000 \mathrm{mg} /$ day mitotane. The doses were adjusted according to clinical severity, UFC, and tolerability (119).

\section{Combined use of drugs targeting corticotrope tumors and adrenal steroidogenesis inhibitors}

There is few published data concerning combined use of cabergoline with ketoconazole. One of the first studies on this subject was published in 2010 (83), involving 12 patients with CD (microadenomas) and active disease after surgical failure. The protocol consisted of initiating treatment with $1 \mathrm{mg} /$ week of cabergoline ( $0.5 \mathrm{mg}$ twice/week), with monthly adjustments of $1 \mathrm{mg} /$ week according to UFC or up to $3 \mathrm{mg} /$ week (1.5 $\mathrm{mg}$ twice/week) for 6 months. UFC normalization occurred in 3 patients $(25 \%)$. In the remaining 9 uncontrolled patients, low dose of ketoconazole (100 mg/day) was added, with monthly adjustments of $100 \mathrm{mg}$ or up to $400 \mathrm{mg} /$ day (200 mg twice/day). Control was achieved in 6/9 patients $(66 \%)$ using both drugs. The remaining 3 patients, those with higher pre-treatment UFC levels (range, $882-991 \mu \mathrm{g} / 24 \mathrm{~h}$, reference 10-90), presented a lower response to cabergoline only. Thus, after 12 months, UFC was controlled in $75 \%$ of patients with cabergoline only or cabergoline + ketoconazole, without escapes during treatment (83). A recent prospective study also assessed this combination therapy in 14 patients with CD by comparing two different regimens: cabergoline followed by ketoconazole $(\mathrm{n}=$ $6)$ vs. ketoconazole followed by cabergoline $(\mathrm{n}=8)$ (84). Cabergoline was initiated at doses of $0.5-1 \mathrm{mg} /$ week up to a maximum of $3 \mathrm{mg}$ with the objective of normalizing UFC and late-night salivary cortisol (NSC). Alternatively, ketoconazole was initiated at a dose of $200 \mathrm{mg} /$ day up to a maximum dose of 600 $\mathrm{mg} /$ day. Regimens were maintained for 6 months. After this treatment period, patients who achieved UFC and NSC normalization were maintained on monotherapy; patients with values outside of normal ranges received combination therapy (either with cabergoline or ketoconazole) for an additional 6 months. In the first 6 months, none of the patients achieved control (UFC and NSC normalization) with cabergoline, although $33 \%$ of patients $(2 / 6)$ achieved UFC normalization. Ketoconazole monotherapy induced control in $62.5 \%$ of patients $(5 / 8)$ at 6 months. UFC normalization occurred in $79 \%$ of patients who were treated with combination therapy, and no differences were observed between the two different combination regimens (84).

Another study evaluated a triple combination regimen with pasireotide, cabergoline and ketoconazole in the preoperative period of 17 patients with CD (99), with the objective of normalizing UFC in 80 days. The treatment was initiated with $100 \mu \mathrm{g}$ SC pasireotide, 3 times per day, up to a maximum of $250 \mu \mathrm{g}$ SC, 3 times per day. The increases were performed according to UFC, and the treatment continued for 30 days. After this period, for patients who did not achieve control, cabergoline was added to the treatment at a dose of 1.5 $\mathrm{mg} /$ week up to a dose of $4.5 \mathrm{mg} /$ week for 30 days. Following this period, patients who did not exhibit a normalized UFC in 60 days with pasireotide + cabergoline received ketoconazole at a dose of $600 \mathrm{mg} /$ day for 20 days. Overall, control was achieved in $29 \%$ of patients with pasireotide monotherapy, $47 \%$ of patients with pasireotide+cabergoline, and in $88 \%$ of patients with the triple combination. However, the achieved control of $88 \%$ does not necessarily mean that all of these patients needed the triple combination. The side effects were worsening of HbAlc levels from $5.8 \pm 0.2$ to $6.7 \pm 0.3 \%$ $(p<0.01)$ and reduction of IGFl to levels lower than reference in $53 \%(9 / 17)(99)$. Although a high rate of control was obtained over a short-term period, this was a small study with an unusual and expensive regimen requiring rapid adjustments, with a potential for 
significative adverse events. Moreover, the outcome of monotherapy with cabergoline and with ketoconazole was not tested. For this reason, more studies enrolling a larger number of patients and, perhaps, exploring different therapeutic sequences are necessary.

\section{Other medications and perspectives}

Temozolomide is an oral, imidazotetrazine alkylating chemotherapy agent used primarily for the adjuvant treatment of cerebral gliomas. This compound has been increasingly used to treat aggressive/atypical pituitary adenomas and pituitary carcinomas. The antitumor activity of temozolomide occurs through its active form, monomethyl-triazen-imidazole-carboxamide (MTIC), which promotes DNA methylation. This action can be neutralized by the presence of the DNA repair enzyme O-6-methylguanine-DNA methyltransferase (MGMT), an effect that can be assessed by immunohistochemistry or real-time reverse transcription PCR (RT-PCR) on tumor tissue. Although most patients who are responsive to temozolomide show low expression of MGMT, recent studies have shown some cases of dissociation between enzyme expression and drug action $(120,121)$. Temozolomide is usually prescribed in monthly 5-day cycles at a dose of $200 \mathrm{mg} / \mathrm{m}^{2} /$ day (tablets, 5/20/100/140/180/250 mg). A review study showed clinical improvement (hormonal and tumor reduction) in $50 \%(4 / 8)$ of patients with corticotrope adenomas and in $83 \%(5 / 6)$ of ACTHproducing pituitary carcinomas (122). Temozolomide is generally well tolerated, and the most significant side effects are leukopenia and thrombocytopenia. This medication is reserved for refractory and aggressive cases, not only ACTH-producing tumors, and tumor escape from its salutary effects may occur (121). It is not approved for CD in either Brazil or the USA, and it is rather costly.

Retinoic acid is known to have in vitro effects on corticotrope tumors and in an animal model of CD (canine) (123-125). The action of retinoic acid is likely mediated by a decrease in ACTH secretion and proopiomelanocortin (POMC) synthesis, as demonstrated in a murine corticotrope cell line by the inhibition of POMC transcription (123). In addition, retinoic acid has an antiproliferative action. In a recent prospective, proof of concept study, 7 patients with CD were treated with retinoic acid (tretinoin) at a dose of $80 \mathrm{mg} /$ day for $6-12$ months. A significant UFC reduction (> 50\%) in $71 \%$ of patients $(5 / 7)$ with normalization in $43 \%$ of cases $(3 / 7)$ was observed (126) and the drug was well tolerated. Another study with $16 \mathrm{CD}$ patients showed UFC normalization in $25 \%$ of cases with isotretinoin use (20-80 mg/day) for 6-12 months (127).

Other drugs have been studied in vitro and in animal models, showing action on corticotrope tumors but still lacking results in patients with $\mathrm{CD}$. These drugs include bexarotene (retinoic acid receptor (RXR) agonist) (72), ( $\alpha$ l-adrenergic receptor antagonist) (128) and gefitinib (EGF receptor antagonist) (129).

Osilodrostat (LCI699) is a new developed steroidogenesis inhibitor. This drug was initially described as an aldosterone synthase inhibitor with potential for the treatment of hypertension (130). Osilodrostat is a potent inhibitor of $11 \beta$-hydroxylase and 18-hydroxylase (98). In a small proof-of-concept study, 10/11 patients with mild to severe CD achieved UFC normalization after 70 days of treatment with 5 $10 \mathrm{mg}$ twice per day. The main side effects were fatigue, nausea, headache, and an ACTH level increase of more than 2 -fold in 5 cases (43). More recent and prolonged study lasting 22 weeks observed normal UFC in $89.5 \%$ $(17 / 19)$ of CD patients (131).

Levoketoconazole is the $2 \mathrm{~S}, 4 \mathrm{R}$ enantiomer of ketoconazole, purified from racemic ketoconazole. In in vitro studies, levoketoconazole was shown to be a more potent inhibitor than the $2 \mathrm{R}, 4 \mathrm{~S}$ enantiomer (132). An open-label, phase III, dose-titration study evaluating levoketoconazole in patients with Cushin's syndrome is ongoing.

Table 1 provides a summary of the drugs used for the treatment of CD.

\section{Radiotherapy}

While used less frequently in patients with GH and prolactin-producing pituitary tumors, radiotherapy is still an important option for adjuvant or rescue treatment in patients with ACTH-producing tumors (133,134).

Pituitary radiotherapy for CD is classically indicated as a secondary treatment after surgical failure. Radiotherapy is also used in uncontrolled patients receiving drug treatment, particularly those with residual or non-resectable tumors (e.g., cavernous sinus invasion). Radiotherapy is rarely used as a primary treatment in cases where surgical treatment is contraindicated. A study performed nearly 40 years 
Table 1. Drug treatment in Cushing's disease

\begin{tabular}{|c|c|c|c|c|c|}
\hline Drug & Initial dose & Maximum Dose & Control* $^{\star}$ & Duration & Observations \\
\hline \multicolumn{6}{|c|}{ Act on the corticotrope tumor } \\
\hline Cabergoline & $\begin{array}{l}0.5 \mathrm{mg} \mathrm{OR} \\
2 \mathrm{x} / \text { week }\end{array}$ & $\begin{array}{c}3 \mathrm{mg} / \text { week } \\
(1-7)\end{array}$ & $25-40 \%$ & $\begin{array}{l}18 \text { months } \\
(3-60)\end{array}$ & $\begin{array}{l}\text { Escape from treatment in 18-30\%; } \\
\text { off label }\end{array}$ \\
\hline Pasireotide & $\begin{array}{c}600 \mu \mathrm{g} \mathrm{SC} \\
2 \mathrm{x} / \text { day }\end{array}$ & $1800 \mu \mathrm{g} /$ day & $29 \%$ & 12 months & Frequent hyperglycemia \\
\hline \multicolumn{6}{|c|}{ Steroidogenesis inhibitors } \\
\hline Ketoconazole & $\begin{array}{l}200 \mathrm{mg} \mathrm{OR} \\
2-3 x / \text { day }\end{array}$ & 1200 mg/day & $52 \%$ & $\begin{array}{l}22 \text { months } \\
(6-72)\end{array}$ & $\begin{array}{l}\text { Escape from treatment in 33\%; mild } \\
\text { common increase in ALT/AST; } \\
\text { improves hirsutism; hypogonadism in men }\end{array}$ \\
\hline Metyrapone & $\begin{array}{l}250 \mathrm{mg} \text { OR } \\
3-4 \mathrm{x} / \text { day }\end{array}$ & $4-6$ g/day & $26-75 \%$ & 4 months & $\begin{array}{l}\text { Rebound increase of ACTH: hirsutism/ } \\
\text { acne, HAS/hypokalemia; N/A }\end{array}$ \\
\hline Etomidate & $\begin{array}{l}\text { IV bolus } 0.03 \mathrm{mg} / \mathrm{kg} \text {; } \\
0.1 \mathrm{mg} / \mathrm{kg} / \mathrm{h}\end{array}$ & $0.3 \mathrm{mg} / \mathrm{kg} / \mathrm{h}$ & $100 \%$ & $\begin{array}{l}7 \text { days } \\
\text { (5 h-56 days) }\end{array}$ & $\begin{array}{l}\text { Used in severe cases; hospital use } \\
\text { (monitoring) }\end{array}$ \\
\hline Mitotane & $500 \mathrm{mg}$ OR/day & 2-3 g/day & $72 \%$ & 7 months & $\begin{array}{l}\text { Frequent side effects; difficult handling; } \\
\text { high cost }\end{array}$ \\
\hline \multicolumn{6}{|c|}{ Cortisol receptor antagonist } \\
\hline Mifepristone & 300 mg OR/day & 1200 mg/day & $\begin{array}{l}60 \% \text { (glycemia } \\
\text { AUC) }\end{array}$ & 24 weeks & $\begin{array}{l}\text { Approved for the control of DM in } \\
\text { Cushing's syndrome; very high cost; N/A }\end{array}$ \\
\hline \multicolumn{6}{|c|}{ Combination therapies } \\
\hline $\begin{array}{l}\text { Ketoconazole + } \\
\text { metyrapone }\end{array}$ & 200/750 mg/day & $1000 / 4500 \mathrm{mg} /$ day & $23 \%$ & 4 months & Metyrapone N/A \\
\hline $\begin{array}{l}\text { Mitotane + metyrapone } \\
+ \text { ketoconazole }\end{array}$ & 3000/2250/800 mg/day & 3000/2250/800 mg/day & $100 \%$ & $<6$ months & Critically ill patients; effect in 24-48 h \\
\hline $\begin{array}{l}\text { Cabergoline + } \\
\text { ketoconazole }\end{array}$ & $1 \mathrm{mg} /$ week/100 mg/day & $3 \mathrm{mg} /$ week/400 mg/day & $75-79 \%$ & 12 months & Short-term studies \\
\hline $\begin{array}{l}\text { Pasireotide + } \\
\text { cabergoline }+ \\
\text { ketoconazole }\end{array}$ & $\begin{array}{l}100 \mu \mathrm{g} \mathrm{SC} 3 x / \text { day/1.5 } \\
\mathrm{mg} / \text { week/600 mg/day }\end{array}$ & $\begin{array}{l}250 \mu \mathrm{g} \mathrm{SC} 3 x / \text { day/4.5 } \\
\mathrm{mg} / \text { week/600 mg/day }\end{array}$ & $88 \%$ & 80 days & $\begin{array}{l}>50 \% \text { IGF1 reduction; frequent } \\
\text { hyperglycemia }\end{array}$ \\
\hline
\end{tabular}

* Control commonly defined as the normalization of 24-hour urinary cortisol; OR: oral route; SC: subcutaneous; ALT/AST: alanine aminotransferase/aspartate aminotransferase; ACTH: adrenocorticotropic hormone; AUC: area under curve; DM: diabetes mellitus; IGF1: insulin-like growth factor 1; N/A: not available.

ago showed better efficacy in the pediatric population than in the adult population and for this reason, radiotherapy has been more utilized in children (135), although this approach is not currently accepted. In addition to hormonal control, another objective of radiotherapy is tumor mass control, either via reduction or stabilization/prevention of growth (i.e., the "oncologic" indication). Usually, the efficacy of tumor mass control is higher than hormonal control, ranging from $83 \%$ to $100 \%(29,134,136)$.

As hormonal control is initiated at least 6 months after radiotherapy (mean, $18-24$ months), there is a need for medical treatment in this interval $(19,29,134)$. In other words, patients should not be followed without medication waiting for the effects of radiotherapy. In patients with effective concomitant clinical treatment, the effect of radiotherapy may be assessed by biannual withdrawn of drug treatment to measure cortisol (e.g., UFC, NSC and/or low dose dexamethasone suppression test (LDDST)) $(19,133)$.

Most data regarding the control rates and prevalence of complications of radiotherapy are derived from older studies that used conventional methods. More modern stereotactic radiotherapy techniques have been developed (i.e., fractionated or single dose), which are potentially more effective and induce less morbidity.

Radiotherapy is usually performed on a welldefined therapeutic target, particularly in the context of single-dose stereotactic radiotherapy (i.e., radiosurgery). However, it is occasionally performed without a clear target lesion in CD and radiation may encompass the entire pituitary tissue, provided that a diagnosis of central origin has been confirmed (e.g., $\mathrm{ACTH}+$ pituitary adenoma, previous PO remission, or central to peripheral ACTH gradient at BIPSS). In cases in which the target is well-defined, single dose 
stereotactic radiotherapy may be performed in lesions up to $4 \mathrm{~cm}$ in diameter, although it is recommended to allow a minimum distance in relation to optic structures (nerves and chiasm) of at least $3-5 \mathrm{~mm}$. In lesions that are close to these structures, fractionated radiotherapy is safer.

Generally, hormonal control is achieved within 2 - 5 years (mean follow-up period, 5 - 10 years) in approximately $50-60 \%$ of cases $(27,29,136)$, regardless of the technique. More recent studies performed with radiosurgery showed a remission rate of approximately $50 \%(45,116,134,137)$ over a similar period ( $4-8$ follow-up years). There is no good evidence of a more rapid effect of radiosurgery in comparison to conventional techniques (136). Some studies recommend drug treatment interruption during radiotherapy sections due to the risk of decreased efficacy (138), but this is a controversial issue.

The main concern regarding radiotherapy is related to potential side effects. The most common is hypopituitarism, which occurs in over $50 \%$ of patients in the long-term. Other reported effects are optical lesions (neuritis, $1-2 \%$ ), radionecrosis of the brain parenchyma $(<1 \%)$, radioinduced secondary tumors (1.5\%) (139), neurocognitive disorders $(<1 \%)$, and cerebrovascular diseases $(<5 \%)$. However, stereotactic techniques, especially radiosurgery that is focused on the lesion and results in less radiation exposure to adjacent tissues, has shown lower complication rates (range, $0-1.3 \%$ ), with the exception of hypopituitarism (72\% in 17 years) (140). It is actually not known whether stereotactic radiotherapy is also associated with an increased risk of secondary tumors since this is a relatively novel treatment modality and long-term dara are lacking.

\section{Adrenalectomy}

Bilateral adrenalectomy is considered a $100 \%$ effective hypercortisolism treatment $(27,141)$. The main advantage of this method is the immediate normalization of cortisol levels. Currently, the surgical procedure is performed through a laparoscopic approach with reduced rate of PO complications and reduced time of hospitalization (141). Some cases may present recurrence of hypercortisolism due to a vicarious increase of ectopic adrenal tissue or adrenal residues after incomplete surgical resections (142).
Adrenalectomy is generally indicated as the last therapeutic option in refractory cases following unsuccessfully surgical, drug and/or radiation treatment. This treatment may also be primarily indicated in severe cases of $\mathrm{CD}$, for which rapid clinical resolution is required, as well as in patients with EAS (143). Finally, adrenalectomy can be performed in women of reproductive age who wish to become pregnant without hormonal stimuli and for whom repeated pituitary surgery and, particularly, radiotherapy could induce hypogonadotropic hypogonadism. One criticism brought up by some authors is related to the long time for adrenalectomy indication, exposing the patients for prolonged hypercortisolism and its catastrophic effects. This situation can be mitigated with treatment optimization based on rapid changes in the therapeutic approach, particularly with medical treatment.

The disadvantages of bilateral adrenalectomy are permanent adrenal insufficiency with the consequent need of lifelong gluco- and mineralocorticoid replacement, the risk of acute crisis in stress situations, and the development of corticotrope tumor progression - Nelson's Syndrome (NS) (144).

Corticotrope tumor progression may occur following adrenalectomy in $21 \%$ of cases over $3-5$ years (145). Predictive risk factors for occurrence of corticotrope tumor progression are younger age, no previous radiotherapy, the presence of pituitary tumor residues or invasive tumors, higher UFC levels and mainly ACTH increase in the first year after adrenalectomy (145). However, there has been controversy regarding the ACTH cutoff level indicating increased risk. Some authors suggested that an increase of plasma ACTH levels $\geq 600$ or $\geq 1000 \mathrm{pg} / \mathrm{mL}$ on the first year after adrenalectomy might indicate tumor progression $(144,146)$. Due to inconsistent data, radiotherapy has not been used as prophylaxis, especially with available pituitary MRI imaging and ACTH measurements that are systematically assessed during the follow-up in order to identify corticotrope tumor progression. Interestingly, although the suggested risk of corticotroph tumor progression has been around $50 \%$ (140), many of these patients do not develop clinical features of Nelson's syndrome with mass effect or skin hyperpigmentation. Thus, is seems that clinical Nelson's syndrome is less common than corticotroph tumor progression after bilateral adrenalectomy. 
Finally, an old study compared remission rate of pituitary surgery with a unilateral adrenalectomy protocol associated with conventional primary pituitary radiotherapy. This report found a similar result of $64 \%$ remission of both strategies (142). However, due to the absence of similar data and a lack of improved surgical remission rates, the clinical applicability of this approach is limited.

\section{Pregnancy}

Pregnancy during active CD is very rare and difficult to handle. The reason for the low prevalence is that hypercortisolism interferes with fertility, particularly due to changes in LH/FSH pulsatility, causing menstrual changes/amenorrhea and anovulation. In addition, an increase in androgen production usually occurs due to ACTH stimulation, which inhibits the normal dynamics of gonadotropins. Perhaps, for this reason, most pregnant patients with $\mathrm{CD}$ are carriers of adrenal adenomas $(40-50 \%)(147-150)$.

Although rare, the identification and correct treatment of this condition is important due to the increased risk of materno-fetal complications (> 70\%) $(147,148)$.

The most common treatment approaches are pituitary surgery, medical therapy, and bilateral adrenalectomy. Expectant approach is also possible when the Cushing's syndrome diagnosis is made at the end of pregnancy, with careful management of associated comorbidities, such as hypertension and diabetes (148). When treatment is indicated, it is usually performed during or after the second trimester due to the time needed to establish the diagnosis. During the gestation period, most pituitary surgeries have a good outcome, and for this reason, pituitary surgery should be the first treatment of choice. Alternatively, during or after the second trimester, drug treatment may be chosen. In this case, metyrapone has been the most reported drug but it is not available in Brazil. The use of has been reported in few cases without the occurrence of congenital malformations (96). However, ketoconazole has been shown to be teratogenic in animal studies and should only be used when metyrapone is not available or induces side effects. There is a single report of cabergoline use in a pregnant patient with $\mathrm{CD}$ (151). In more severe and unresponsive cases, as well as in adrenal-related disease, adrenalectomies have been performed in several patients $(147,148)$ and are generally effective.

Table 2 summarizes indications for therapeutic options in $\mathrm{CD}$, and Figure 1 shows a proposed treatment algorithm.

Role of the authors: the authors of this review comprise an expert committee that was gathered in order to provide an updated review of the treatment of Cushing's disesase through the contribution of each author.

Review methods: The lead author performed a PubMed search of CD treatment and discussed with the senior author. The review was then drafted and circulated to the members of the committee who provided with numerous contributions to the final text.

Disclosure: no potential conflict of interest relevant to this article was reported.

Table 2. Therapeutic options in Cushing's disease

\begin{tabular}{|c|c|c|c|c|}
\hline Type & Control* & Advantage & Disadvantage & Observations \\
\hline Pituitary surgery & $\begin{array}{c}\text { MIC: } \\
70-90 \% \\
\text { MAC: } \\
50-70 \%\end{array}$ & Rapid; direct & $\begin{array}{l}\text { Lower remission in invasive macros, } \\
\text { and when tumor not visible in image }\end{array}$ & General treatment of choice \\
\hline Subsequent pituitary surgery & $40-70 \%$ & Possibility of definitive resolution & $\begin{array}{l}\text { Lower remission compared to first } \\
\text { surgery; increases the risk of } \\
\text { cerebrospinal fluid fistula and } \\
\text { hypopituitarism }\end{array}$ & $\begin{array}{l}\text { Best suited for patients with } \\
\text { persistence of tumoral image }\end{array}$ \\
\hline Drug treatment & $40-100 \%$ & $\begin{array}{l}\text { Noninvasive; allows patients to } \\
\text { undergo surgery if needed }\end{array}$ & Chronic use; side effects & $\begin{array}{c}\text { Mainly indicated in surgical failure, } \\
\text { and after RTX }\end{array}$ \\
\hline Stereotactic radiotherapy & $50-60 \%$ & Direct treatment & $\begin{array}{l}\text { Slow start; side effects } \\
\text { (hypopituitarism) }\end{array}$ & Associated with drug treatment \\
\hline Bilateral adrenalectomy & $100 \%$ & Immediate control & $\begin{array}{l}\text { Risk of corticotrope tumor } \\
\text { progression; permanent gluco- and } \\
\text { mineralocorticoid insufficiency }\end{array}$ & $\begin{array}{l}\text { Indicated in severe cases, refractory } \\
\text { cases, and when pregnancy is } \\
\text { desired }\end{array}$ \\
\hline
\end{tabular}

* Control of urine free cortisol; MIC: microadenoma; MAC: macroadenoma; RTX: radiotherapy. 


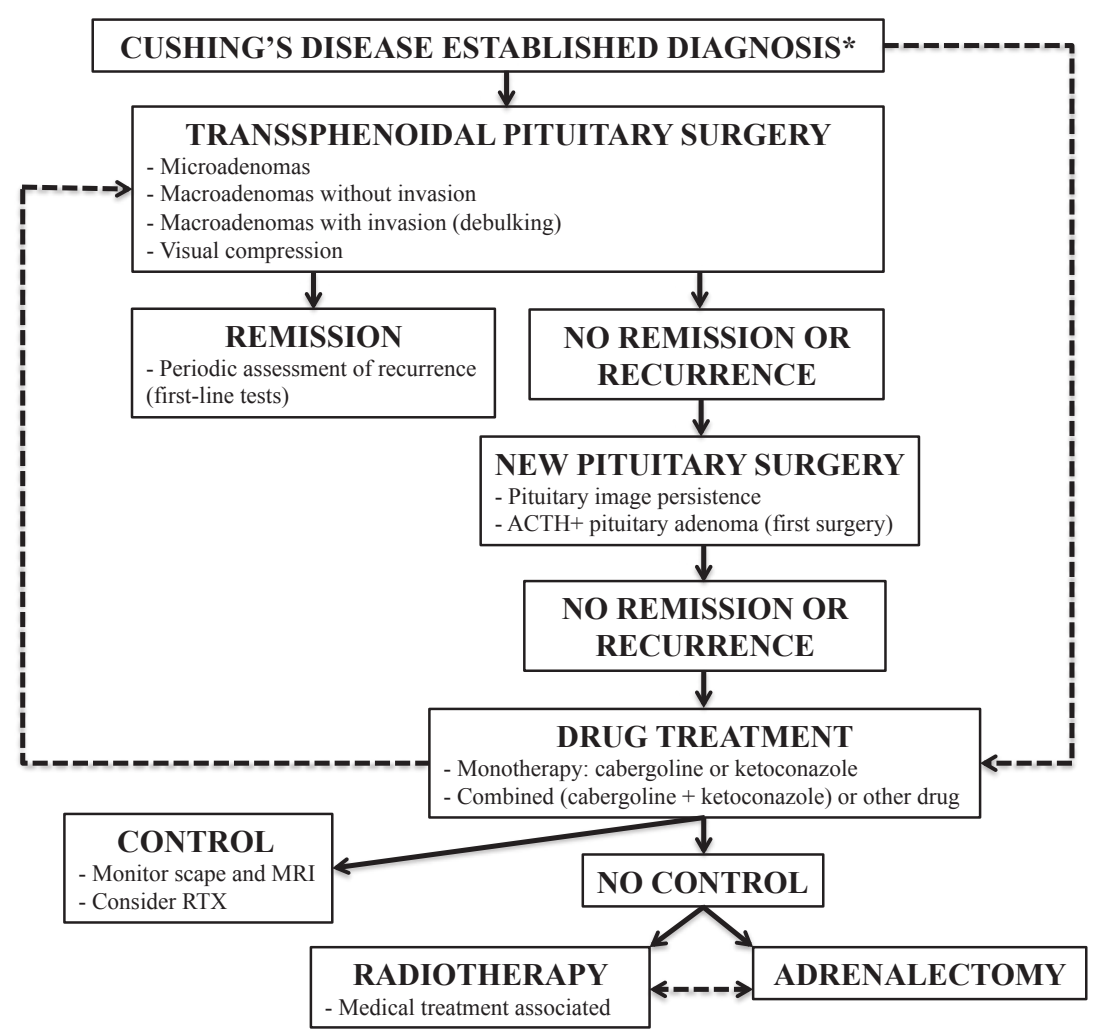

Figure 1. Treatment algorithm for the treatment of Cushing's disease.

* Primary clinical treatment may be considered in patients with a contraindication to surgery, those who need to improve preoperative clinical conditions, those who refuse surgical treatment, and in case an experienced surgeon is unavailable. Pituitary surgery should be performed in tertiary centers by experienced surgeons, and patient referral should be considered when these conditions cannot be achieved. Very severe cases may undergo initial bilateral adrenalectomy.

RTX: pituitary radiotherapy.

\section{REFERENCES}

1. Etxabe J, Vazquez JA. Morbidity and mortality in Cushing's disease: an epidemiological approach. Clin Endocrinol (Oxf). 1994;40(4):479-84.

2. Swearingen B, Biller BM, Barker FG 2nd, Katznelson L, Grinspoon S, Klibanski A, et al. Long-term mortality after transsphenoidal surgery for Cushing disease. Ann Intern Med. 1999;130(10):821-4.

3. Pikkarainen L, Sane T, Reunanen A. The survival and well-being of patients treated for Cushing's syndrome. J Intern Med. 1999;245(5):463-8.

4. Lindholm J, Juul S, Jørgensen JO, Astrup J, Bjerre P, FeldtRasmussen $U$, et al. Incidence and late prognosis of cushing's syndrome: a population-based study. J Clin Endocrinol Metab. 2001;86(1):117-23.

5. Hammer GD, Tyrrell JB, Lamborn KR, Applebury CB, Hannegan ET, Bell S, et al. Transsphenoidal microsurgery for Cushing's disease: initial outcome and long-term results. J Clin Endocrinol Metab. 2004;89(12):6348-57.

6. Dekkers OM, Biermasz NR, Pereira AM, Roelfsema F, van Aken MO, Voormolen $\mathrm{JH}$, et al. Mortality in patients treated for Cushing's disease is increased, compared with patients treated for nonfunctioning pituitary macroadenoma. J Clin Endocrinol Metab. 2007;92(3):976-81.

7. Clayton RN, Raskauskiene D, Reulen RC, Jones PW. Mortality and morbidity in Cushing's disease over 50 years in Stoke-on-
Trent, UK: audit and meta-analysis of literature. J Clin Endocrinol Metab. 2011;96(3):632-42.

8. Lambert JK, Goldberg L, Fayngold S, Kostadinov J, Post KD, Geer EB. Predictors of mortality and long-term outcomes in treated Cushing's disease: a study of 346 patients. J Clin Endocrinol Metab. 2013;98(3):1022-30.

9. Dekkers OM, Horváth-Puhó E, Jørgensen JO, Cannegieter SC, Ehrenstein V, Vandenbroucke JP, et al. Multisystem morbidity and mortality in Cushing's syndrome: a cohort study. J Clin Endocrinol Metab. 2013;98(6):2277-84.

10. Clayton RN, Jones PW, Reulen RC, Stewart PM, Hassan-Smith ZK, Ntali G, et al. Mortality in patients with Cushing's disease more than 10 years after remission: a multicentre, multinational, retrospective cohort study. Lancet Diabetes Endocrinol. 2016;4(7):569-76.

11. Colao A, Pivonello R, Spiezia S, Faggiano A, Ferone D, Filippella $M$, et al., Persistence of increased cardiovascular risk in patients with Cushing's disease after five years of successful cure. J Clin Endocrinol Metab. 1999;84(8):2664-72.

12. Barahona MJ, Resmini E, Viladés D, Pons-Lladó G, Leta R, Puig $\mathrm{T}$, et al. Coronary artery disease detected by multislice computed tomography in patients after long-term cure of Cushing's syndrome. J Clin Endocrinol Metab. 2013;98(3):1093-9.

13. Santos A, Crespo I, Aulinas A, Resmini E, Valassi E, Webb SM. Quality of life in Cushing's syndrome. Pituitary. 2015;18(2):195200. 
14. Flitsch J, Lüdecke DK, Knappe UJ, Grzyska U. Cavernous sinus sampling in selected cases of Cushing's disease. Exp Clin Endocrinol Diabetes. 2002;110(7):329-35.

15. Martínez Ruiz M, Gómez Bueno O, Molina Rodríguez MA, González Casado I, Gracia Bouthelier R. [Diagnosis, treatment and long-term outcome in Cushing's disease]. An Pediatr (Barc). 2003;59(2):183-6.

16. Bolland MJ, Holdaway IM, Berkeley JE, Lim S, Dransfield WJ, Conaglen JV, et al. Mortality and morbidity in Cushing's syndrome in New Zealand. Clin Endocrinol (Oxf). 2011;75(4):436-42.

17. Valassi $E$, Santos A, Yaneva M, Tóth M, Strasburger CJ, Chanson $\mathrm{P}$, et al. The European Registry on Cushing's syndrome: 2-year experience. Baseline demographic and clinical characteristics. Eur J Endocrinol. 2011;165(3):383-92.

18. Nieman LK. Update in the medical therapy of Cushing's disease. Curr Opin Endocrinol Diabetes Obes. 2013;20(4):330-4.

19. Nieman LK, Biller BM, Findling JW, Murad MH, Newell-Price $\mathrm{J}$, Savage MO, et al. Treatment of Cushing's Syndrome: An Endocrine Society Clinical Practice Guideline. J Clin J Clin Endocrinol Metab. 2015;100(8):2807-31.

20. Van Zaane B, Nur E, Squizzato A, Dekkers OM, Twickler MT, Fliers $\mathrm{E}$, et al. Hypercoagulable state in Cushing's syndrome: a systematic review. J Clin Endocrinol Metab, J Clin Endocrinol Metab. 2009;94(8):2743-50.

21. Koutroumpi S, Daidone V, Sartori MT, Cattini MG, Albiger NM, Occhi G, et al. Venous thromboembolism in patients with Cushing's syndrome: need of a careful investigation of the prothrombotic risk profile. Pituitary. 2013;16(2):175-81.

22. van der Pas R, de Bruin C, Leebeek FW, de Maat MP, Rijken DC, Pereira AM, et al. The hypercoagulable state in Cushing's disease is associated with increased levels of procoagulant factors and impaired fibrinolysis, but is not reversible after shortterm biochemical remission induced by medical therapy. J Clin Endocrinol Metab. 2012;97(4):1303-10.

23. van der Pas R, Leebeek FW, Hofland LJ, de Herder WW, Feelders RA. Hypercoagulability in Cushing's syndrome: prevalence, pathogenesis and treatment. Clin Endocrinol (Oxf). 2013;78(4):481-8.

24. Kastelan D, DusekT, Kraljevic I, Aganovic I. Hypercoagulable state in Cushing's syndrome is reversible following remission. Clin Endocrinol (Oxf). 2013;78(1):102-6.

25. Zilio M, Mazzai L, Sartori MT, Barbot M, Ceccato F, Daidone V, et al. $A$ venous thromboembolism risk assessment model for patients with Cushing's syndrome. Endocrine. 2016;52(2):322-32.

26. Coelho MC, Santos CV, Vieira Neto L, Gadelha MR. Adverse effects of glucocorticoids: coagulopathy. Eur J Endocrinol. 2015;173(4):M11-21.

27. Biller BM, Grossman AB, Stewart PM, Melmed S, Bertagna $X$, Bertherat J, et al., Treatment of adrenocorticotropin-dependent Cushing's syndrome: a consensus statement. J Clin Endocrinol Metab. 2008;93(7):2454-62.

28. Czepielewski MA, Rollin GA, Casagrande A, Ferreira NP. Criteria of cure and remission in Cushing's disease: an update. Arq Bras Endocrinol Metabol. 2007;51(8):1362-72.

29. Tritos NA, Biller BM, Swearingen B. Management of Cushing disease. Nat Rev Endocrinol. 2011;7(5):279-89.

30. Sheth SA, Bourne SK, Tritos NA, Swearingen B. Neurosurgical treatment of Cushing disease. Neurosurg Clin $N$ Am. 2012;23(4):639-51.

31. Fomekong E, Maiter D, Grandin C, Raftopoulos C. Outcome of transsphenoidal surgery for Cushing's disease: a high remission rate in $\mathrm{ACTH}$-secreting macroadenomas. Clin Neurol Neurosurg. 2009;111(5):442-9.

32. Yamada S, Fukuhara N, Nishioka H, Takeshita A, Inoshita N, Ito $\mathrm{J}$, et al. Surgical management and outcomes in patients with
Cushing disease with negative pituitary magnetic resonance imaging. World Neurosurg. 2012;77(3-4):525-32.

33. Jehle S, Walsh JE, Freda PU, Post KD. Selective use of bilateral inferior petrosal sinus sampling in patients with adrenocorticotropin-dependent Cushing's syndrome prior to transsphenoidal surgery. J Clin Endocrinol Metab. 2008;93(12):4624-32.

34. Devoe DJ, Miller WL, Conte FA, Kaplan SL, Grumbach MM, Rosenthal SM, et al. Long-term outcome in children and adolescents after transsphenoidal surgery for Cushing's disease. J Clin Endocrinol Metab. 1997;82(10):3196-202.

35. Lonser RR, Wind JJ, Nieman LK, Weil RJ, DeVroom HL, Oldfield $\mathrm{EH}$. Outcome of surgical treatment of 200 children with Cushing's disease. J Clin Endocrinol Metab. 2013;98(3):892-901.

36. Atkinson JL, Young WF Jr, Meyer FB, Davis DH, Nippoldt TB, Erickson D, et al. Sublabial transseptal vs transnasal combined endoscopic microsurgery in patients with Cushing disease and MRI-depicted microadenomas. Mayo Clin Proc. 2008;83(5):550-3.

37. Starke RM, Reames DL, Chen CJ, Laws ER, Jane JA Jr. Endoscopic transsphenoidal surgery for cushing disease: techniques, outcomes, and predictors of remission. Neurosurgery. 2013;72(2):240-7; discussion 247.

38. Alahmadi H, Cusimano MD, Woo K, Mohammed AA, Goguen J, Smyth HS, et al. Impact of technique on cushing disease outcome using strict remission criteria. Can J Neurol Sci. 2013;40(3):334-41.

39. Storr HL, Drake WM, Evanson J, Matson M, Berney DM, Grossman $A B$, et al. Endonasal endoscopic transsphenoidal pituitary surgery: early experience and outcome in paediatric Cushing's disease. Clin Endocrinol (Oxf). 2014;80(2):270-6.

40. Pendharkar AV, Sussman ES, Ho AL, Hayden Gephart MG, Katznelson L. Cushing's disease: predicting long-term remission after surgical treatment. Neurosurg Focus. 2015;38(2):E13.

41. Semple PL, Laws ER Jr. Complications in a contemporary series of patients who underwent transsphenoidal surgery for Cushing's disease. J Neurosurg. 1999;91(2):175-9.

42. Bochicchio D, Losa M, Buchfelder M. Factors influencing the immediate and late outcome of Cushing's disease treated by transsphenoidal surgery: a retrospective study by the European Cushing's Disease Survey Group. J Clin Endocrinol Metab. 1995;80(11):3114-20.

43. Bertagna $X$, Pivonello $R$, Fleseriu $M$, Zhang $Y$, Robinson P, Taylor $A$, et al. LCI699, a potent $11 \beta$-hydroxylase inhibitor, normalizes urinary cortisol in patients with Cushing's disease: results from a multicenter, proof-of-concept study. J Clin Endocrinol Metab. 2014;99(4):1375-83.

44. Yap LB, Turner HE, Adams CB, Wass JA. Undetectable postoperative cortisol does not always predict long-term remission in Cushing's disease: a single centre audit. Clin Endocrinol (Oxf). 2002;56(1):25-31.

45. Patil CG, Prevedello DM, Lad SP, Vance ML, Thorner MO, Katznelson $L$, et al. Late recurrences of Cushing's disease after initial successful transsphenoidal surgery. J Clin Endocrinol Metab. 2008;93(2):358-62.

46. Lindsay JR, Oldfield EH, Stratakis CA, Nieman LK. The postoperative basal cortisol and $\mathrm{CRH}$ tests for prediction of longterm remission from Cushing's disease after transsphenoidal surgery. J Clin Endocrinol Metab. 2011;96(7):2057-64.

47. Valassi E, Biller BM, Swearingen B, Pecori Giraldi F, Losa M, Mortini $P$, et al., Delayed remission after transsphenoidal surgery in patients with Cushing's disease. J Clin Endocrinol Metab. 2010;95(2):601-10.

48. AbdelMannan D, Selman WR, Arafah BM. Peri-operative management of Cushing's disease. Rev Endocr Metab Disord. 2010;11(2):127-34. 
49. Abdelmannan D, Chaiban J, Selman WR, Arafah BM. Recurrences of ACTH-secreting adenomas after pituitary adenomectomy can be accurately predicted by perioperative measurements of plasma ACTH levels. J Clin Endocrinol Metab. 2013;98(4):1458-65.

50. Pivonello R, Ferone D, de Herder WW, de Krijger RR, Waaijers $\mathrm{M}$, Mooij DM, et al. Dopamine receptor expression and function in human normal adrenal gland and adrenal tumors. J Clin Endocrinol Metab. 2004;89(9):4493-502.

51. Nilsson AG, Marelli C, Fitts D, Bergthorsdottir R, Burman $P$, Dahlqvist $P$, et al. Prospective evaluation of long-term safety of dual-release hydrocortisone replacement administered once daily in patients with adrenal insufficiency. Eur $\mathrm{J}$ Endocrinol. 2014;171(3):369-77.

52. Srinivasan L, Laws ER, Dodd RL, Monita MM, Tannenbaum CE, Kirkeby KM, et al. The dynamics of post-operative plasma ACTH values following transsphenoidal surgery for Cushing's disease. Pituitary. 2011;14(4):312-7.

53. Hameed N, Yedinak CG, Brzana J, Gultekin SH, Coppa ND, Dogan $A$, et al. Remission rate after transsphenoidal surgery in patients with pathologically confirmed Cushing's disease, the role of cortisol, ACTH assessment and immediate reoperation: a large single center experience. Pituitary. 2013;16(4):452-8.

54. Carrasco CA, Coste J, Guignat L, Groussin L, Dugué MA, Gaillard $\mathrm{S}$, et al. Midnight salivary cortisol determination for assessing the outcome of transsphenoidal surgery in Cushing's disease. J Clin Endocrinol Metab. 2008;93(12):4728-34.

55. Danet-Lamasou M, Asselineau J, Perez P, Vivot A, Nunes ML, Loiseau $\mathrm{H}$, et al. Accuracy of repeated measurements of latenight salivary cortisol to screen for early-stage recurrence of Cushing's disease following pituitary surgery. Clin Endocrinol (Oxf). 2015;82(2):260-6.

56. Amlashi FG, Swearingen B, Faje AT, Nachtigall LB, Miller KK, Klibanski A, et al., Accuracy of Late-Night Salivary Cortisol in Evaluating Postoperative Remission and Recurrence in Cushing's Disease. J Clin Endocrinol Metab. 2015;100(10):3770-7.

57. Colombo P, Dall'Asta C, Barbetta L, Re T, Passini E, Faglia G, et al. Usefulness of the desmopressin test in the postoperative evaluation of patients with Cushing's disease. Eur $\mathrm{J}$ Endocrinol. 2000;143(2):227-34.

58. Barbetta L, Dall'Asta C, Tomei G, Locatelli M, Giovanelli M, Ambrosi B. Assessment of cure and recurrence after pituitary surgery for Cushing's disease. Acta Neurochir (Wien). 2001;143(5):477-81; discussion 481-2.

59. Losa M, Mortini P, Dylgjeri S, Barzaghi R, Franzin A, Mandelli C, et al. Desmopressin stimulation test before and after pituitary surgery in patients with Cushing's disease. Clin Endocrinol (Oxf). 2001;55(1):61-8.

60. Valéro R, Vallette-Kasic $S$, Conte-Devolx B, Jaquet $P$, Brue T. The desmopressin test as a predictive factor of outcome after pituitary surgery for Cushing's disease. Eur J Endocrinol. 2004;151(6):727-33.

61. Dall'Asta C, Barbetta L, Bonavina L, Beck-Peccoz P, Ambrosi B. Recurrence of Cushing's disease preceded by the reappearance of ACTH and cortisol responses to desmopressin test. Pituitary. 2004;7(3):183-8.

62. Romanholi DJ, Machado MC, Pereira CC, Danilovic DS, Pereira MA, Cescato VA, et al. Role for postoperative cortisol response to desmopressin in predicting the risk for recurrent Cushing's disease. Clin Endocrinol (Oxf). 2008;69(1):117-22.

63. Losa M, Bianchi R, Barzaghi R, Giovanelli M, Mortini P. Persistent adrenocorticotropin response to desmopressin in the early postoperative period predicts recurrence of Cushing's disease. J Clin Endocrinol Metab. 2009;94(9):3322-8.
64. Ambrosi B, Malavazos A, Passeri E, Dall'Asta C. Desmopressin test may predict the risk of recurrence in Cushing's disease. Clin Endocrinol (Oxf). 2009;70(5):811.

65. Liubinas SV, Porto LD, Kaye AH. Management of recurrent Cushing's disease. J Clin Neurosci. 2011;18(1):7-12.

66. Wagenmakers MA, Boogaarts HD, Roerink SH, Timmers HJ, Stikkelbroeck NM, Smit JW, et al. Endoscopic transsphenoidal pituitary surgery: a good and safe primary treatment option for Cushing's disease, even in case of macroadenomas or invasive adenomas. Eur J Endocrinol. 2013;169(3):329-37.

67. Valderrábano P, Aller J, García-Valdecasas L, García-Uría J, Martín $\mathrm{L}$, Palacios N, et al. Results of repeated transsphenoidal surgery in Cushing's disease. Long-term follow-up. Endocrinol Nutr. 2014;61(4):176-83.

68. Trainer PJ, Lawrie HS, Verhelst J, HowlettTA, Lowe DG, Grossman $A B$, et al. Transsphenoidal resection in Cushing's disease: undetectable serum cortisol as the definition of successful treatment. Clin Endocrinol (Oxf). 1993;38(1):73-8.

69. Ram Z, Nieman LK, Cutler GB Jr, Chrousos GP, Doppman JL, Oldfield EH. Early repeat surgery for persistent Cushing's disease. J Neurosurg. 1994;80(1):37-45.

70. Locatelli M, Vance ML, Laws ER. Clinical review: the strategy of immediate reoperation for transsphenoidal surgery for Cushing's disease. J Clin Endocrinol Metab. 2005;90(9):5478-82.

71. Fleseriu M, Biller BM, Findling JW, Molitch ME, Schteingart DE, Gross C; SEISMIC Study Investigators. Mifepristone, a glucocorticoid receptor antagonist, produces clinical and metabolic benefits in patients with Cushing's syndrome. J Clin Endocrinol Metab. 2012;97(6):2039-49.

72. Tritos NA, Biller BM. Advances in medical therapies for Cushing's syndrome. Discov Med. 2012;13(69):171-9.

73. Feelders RA, Hofland LJ. Medical treatment of Cushing's disease. J Clin Endocrinol Metab. 2013;98(2):425-38.

74. Gadelha MR, Vieira Neto L. Efficacy of medical treatment in Cushing's disease: a systematic review. Clin Endocrinol (Oxf). 2014;80(1):1-12.

75. Hamrahian AH,Yuen KC, Hoffman AR; AACE Neuroendocrine And Pituitary Scientific Committee. AACE/ACE Disease State Clinical Review: Medical Management of Cushing Disease. Endocr Pract. 2014;20(7):746-57.

76. Tritos NA, Biller BM. Medical management of Cushing's disease. J Neurooncol. 2014;117(3):407-14.

77. Cuevas-Ramos D, Fleseriu M. Treatment of Cushing's disease: a mechanistic update. J Endocrinol. 2014;223(2):R19-39.

78. Molitch ME. Current approaches to the pharmacological management of Cushing's disease. Mol Cell Endocrinol. 2015;408:185-9.

79. Fleseriu M. Medical treatment of Cushing disease: new targets, new hope. Endocrinol Metab Clin North Am. 2015;44(1):51-70.

80. Lau D, Rutledge C, Aghi MK. Cushing's disease: current medical therapies and molecular insights guiding future therapies. Neurosurg Focus. 2015;38(2):E11.

81. Pivonello R, De Martino MC, Cappabianca P, De Leo M, Faggiano A, Lombardi G, et al. The medical treatment of Cushing's disease: effectiveness of chronic treatment with the dopamine agonist cabergoline in patients unsuccessfully treated by surgery. J Clin Endocrinol Metab. 2009;94(1):223-30.

82. Godbout A, Manavela M, Danilowicz K, Beauregard H, Bruno OD, Lacroix A. Cabergoline monotherapy in the long-term treatment of Cushing's disease. Eur J Endocrinol. 2010;163(5):709-16.

83. Vilar L, Naves LA, Azevedo MF, Arruda MJ, Arahata CM, Moura E, et al. Effectiveness of cabergoline in monotherapy and combined with ketoconazole in the management of Cushing's disease. Pituitary. 2010;13(2):123-9. 
84. Barbot M, Albiger N, Ceccato F, Zilio M, Frigo AC, Denaro L, et al. Combination therapy for Cushing's disease: effectiveness of two schedules of treatment: should we start with cabergoline or ketoconazole? Pituitary. 2014;17(2):109-17.

85. Burman P, Edén-Engström B, Ekman B, Karlsson FA, Schwarcz E, Wahlberg J. Limited value of cabergoline in Cushing's disease: a prospective study of a 6 -week treatment in 20 patients. Eur $\mathrm{J}$ Endocrinol. 2016;174(1):17-24.

86. Miyoshi T, Otsuka F, Takeda M, Inagaki K, Suzuki J, Ogura T, et al. Effect of cabergoline treatment on Cushing's disease caused by aberrant adrenocorticotropin-secreting macroadenoma. J Endocrinol Invest. 2004;27(11):1055-9.

87. Manavela MP, Danilowicz K, Bruno OD. Macrocorticotropinoma shrinkage and control of hypercortisolism under long-term cabergoline therapy: case report. Pituitary. 2012;15 Suppl 1:33-6.

88. Schade R, Andersohn F, Suissa S, Haverkamp W, Garbe E. Dopamine agonists and the risk of cardiac-valve regurgitation. $\mathrm{N}$ Engl J Med. 2007;356(1):29-38.

89. van der Hoek J, Lamberts SW, Hofland LJ.The role of somatostatin analogs in Cushing's disease. Pituitary. 2004;7(4):257-64.

90. van der Hoek J, Lamberts SW, Hofland LJ. Preclinical and clinical experiences with the role of somatostatin receptors in the treatment of pituitary adenomas. Eur J Endocrinol. 2007;156 Suppl 1:S45-51.

91. Trementino L, Michetti G, Angeletti A, Marcelli G, Concettoni C, Cardinaletti $C$, et al. A Single-Center 10-Year Experience with Pasireotide in Cushing's Disease: Patients' Characteristics and Outcome. Horm Metab Res. 2016;48(5):290-8.

92. Hofland LJ, van der Hoek J, Feelders R, van Aken MO, van Koetsveld PM, Waaijers M, et al. The multi-ligand somatostatin analogue SOM230 inhibits ACTH secretion by cultured human corticotroph adenomas via somatostatin receptor type 5 . Eur J Endocrinol. 2005;152(4):645-54.

93. Dickerman RD, Oldfield EH. Basis of persistent and recurrent Cushing disease: an analysis of findings at repeated pituitary surgery. J Neurosurg. 2002;97(6):1343-9.

94. Boscaro M, Ludlam WH, Atkinson B, Glusman JE, Petersenn $\mathrm{S}$, Reincke $\mathrm{M}$, et al. Treatment of pituitary-dependent Cushing's disease with the multireceptor ligand somatostatin analog pasireotide (SOM230): a multicenter, phase II trial. J Clin Endocrinol Metab. 2009;94(1):115-22.

95. Colao A, Petersenn S, Newell-Price J, Findling JW, Gu F, Maldonado $\mathrm{M}$, et al. A 12-month phase 3 study of pasireotide in Cushing's disease. N Engl J Med. 2012;366(10):914-24.

96. Boscaro $M$, Bertherat J, Findling J, Fleseriu $M$, Atkinson $A B$, Petersenn $S$, et al. Extended treatment of Cushing's disease with pasireotide: results from a 2-year, Phase II study. Pituitary. 2014;17(4):320-6.

97. Trementino L, Cardinaletti M, Concettoni C, Marcelli G, Boscaro $M$, Arnaldi G. Up-to 5-year efficacy of pasireotide in a patient with Cushing's disease and pre-existing diabetes: literature review and clinical practice considerations. Pituitary. 2015;18(3):359-65.

98. Amar L, Azizi M, Menard J, Peyrard S, Watson C, Plouin PF. Aldosterone synthase inhibition with LCl699: a proof-of-concept study in patients with primary aldosteronism. Hypertension. 2010;56(5):831-8.

99. Feelders RA, de Bruin C, Pereira AM, Romijn JA, Netea-Maier RT, Hermus AR, et al. Pasireotide alone or with cabergoline and ketoconazole in Cushing's disease. $\mathrm{N}$ Engl J Med. 2010;362(19):1846-8.

100. Castinetti F, Guignat L, Giraud P, Muller M, Kamenicky P, Drui D, et al. Ketoconazole in Cushing's disease: is it worth a try? J Clin Endocrinol Metab. 2014;99(5):1623-30.
101. Castinetti F, Morange I, Jaquet P, Conte-Devolx B, Brue T. Ketoconazole revisited: a preoperative or postoperative treatment in Cushing's disease. Eur J Endocrinol. 2008;158(1):91-9.

102. Sonino N, Boscaro M, Paoletta A, Mantero F, Ziliotto D Ketoconazole treatment in Cushing's syndrome: experience in 34 patients. Clin Endocrinol (Oxf). 1991;35(4):347-52.

103. Loli P, Berselli ME, Tagliaferri M. Use of ketoconazole in the treatment of Cushing's syndrome. J Clin Endocrinol Metab. 1986;63(6):1365-71.

104. McCance DR, Hadden DR, Kennedy L, Sheridan B, Atkinson AB. Clinical experience with ketoconazole as a therapy for patients with Cushing's syndrome. Clin Endocrinol (Oxf). 1987;27(5):593-9.

105. Cerdas S, Billaud L, Guilhaume B, Laudat MH, Bertagna X, Luton JP. [Short term effects of ketoconazole in Cushing's syndrome]. Ann Endocrinol (Paris). 1989;50(6):489-96.

106. Mortimer RH, Cannell GR, Thew CM, Galligan JP. Ketoconazole and plasma and urine steroid levels in Cushing's disease. Clin Exp Pharmacol Physiol. 1991;18(8):563-9.

107. Engelhardt D, Weber MM. Therapy of Cushing's syndrome with steroid biosynthesis inhibitors. J Steroid Biochem Mol Biol. 1994;49(4-6):261-7.

108. Valassi E, Crespo I, Santos A, Webb SM. Clinical consequences of Cushing's syndrome. Pituitary. 2012;15(3):319-29.

109. Greenblatt HK, Greenblatt DJ. Liver injury associated with ketoconazole: review of the published evidence. J Clin Pharmacol. 2014;54(12):1321-9.

110. Verhelst JA, Trainer PJ, Howlett TA, Perry L, Rees LH, Grossman $A B$, et al. Short and long-term responses to metyrapone in the medical management of 91 patients with Cushing's syndrome. Clin Endocrinol (Oxf). 1991;35(2):169-78.

111. Daniel E, Aylwin S, Mustafa O, Ball S, Munir A, Boelaert K, et al. Effectiveness of Metyrapone in Treating Cushing's Syndrome: A Retrospective Multicenter Study in 195 Patients. J Clin Endocrinol Metab. 2015;100(11):4146-54.

112. Heyn J, Geiger C, Hinske CL, Briegel J, Weis F. Medical suppression of hypercortisolemia in Cushing's syndrome with particular consideration of etomidate. Pituitary. 2012;15(2):117-25.

113. Preda VA, Sen J, Karavitaki N, Grossman AB. Etomidate in the management of hypercortisolaemia in Cushing's syndrome: a review. Eur J Endocrinol. 2012;167(2):137-43.

114. Baudry C, Coste J, Bou Khalil R, Silvera S, Guignat L, Guibourdenche $\mathrm{J}$, et al. Efficiency and tolerance of mitotane in Cushing's disease in 76 patients from a single center. Eur $\mathrm{J}$ Endocrinol. 2012;167(4):473-81.

115. Pozza C, Graziadio C, Giannetta E, Lenzi A, Isidori AM. Management Strategies for Aggressive Cushing's Syndrome: From Macroadenomas to Ectopics. J Oncol. 2012;2012:685213.

116. Castinetti F, Fassnacht M, Johanssen S, Terzolo M, Bouchard $P$, Chanson $\mathrm{P}$, et al. Merits and pitfalls of mifepristone in Cushing's syndrome. Eur J Endocrinol. 2009;160(6):1003-10.

117. Fleseriu M, Findling JW, Koch CA, Schlaffer SM, Buchfelder M, Gross C. Changes in plasma ACTH levels and corticotroph tumor size in patients with Cushing's disease during long-term treatment with the glucocorticoid receptor antagonist mifepristone. J Clin Endocrinol Metab. 2014;99(10):3718-27.

118. Vilar L, Naves LA, Machado MC, Bronstein MD. Medical combination therapies in Cushing's disease. Pituitary. 2015;18(2):253-62.

119. Kamenický P, Droumaguet C, Salenave S, Blanchard A, Jublanc C, Gautier JF, et al. Mitotane, metyrapone, and ketoconazole combination therapy as an alternative to rescue adrenalectomy for severe ACTH-dependent Cushing's syndrome. J Clin Endocrinol Metab. 2011;96(9):2796-804. 
120. Raverot G, Castinetti F, Jouanneau E, Morange I, FigarellaBranger $\mathrm{D}$, Dufour $\mathrm{H}$, et al. Pituitary carcinomas and aggressive pituitary tumours: merits and pitfalls of temozolomide treatment. Clin Endocrinol (Oxf). 2012;76(6):769-75.

121. Raverot G, Wierinckx A, Jouanneau E, Auger C, Borson-Chazot $F$, Lachuer J, et al. Clinical, hormonal and molecular characterization of pituitary ACTH adenomas without (silent corticotroph adenomas) and with Cushing's disease. Eur J Endocrinol. 2010;163(1):35-43.

122. McCormack Al1, Wass JA, Grossman AB. Grossman, Aggressive pituitary tumours: the role of temozolomide and the assessment of MGMT status. Eur J Clin Invest. 2011;41(10):1133-48.

123. Páez-Pereda M, Kovalovsky D, Hopfner U, Theodoropoulou M, Pagotto U, Uhl E, et al. Retinoic acid prevents experimental Cushing syndrome. J Clin Invest. 2001;108(8):1123-31.

124. Castillo V, Giacomini D, Páez-Pereda M, Stalla J, Labeur M, Theodoropoulou M, et al. Retinoic acid as a novel medical therapy for Cushing's disease in dogs. Endocrinology. 2006;147(9):4438-44.

125. Labeur M, Paez-Pereda M, Arzt E, Stalla GK. Potential of retinoic acid derivatives for the treatment of corticotroph pituitary adenomas. Rev Endocr Metab Disord. 2009;10(2):103-9.

126. Pecori Giraldi F, Ambrogio AG, Andrioli M, Sanguin F, Karamouzis I, Corsello SM, et al., Potential role for retinoic acid in patients with Cushing's disease. J Clin Endocrinol Metab. 2012;97(10):3577-83.

127. Vilar L, Albuquerque JL, Lyra R, Trovão Diniz E, Rangel Filho $F$, Gadelha P, et al., The Role of Isotretinoin Therapy for Cushing's Disease: Results of a Prospective Study. Int J Endocrinol. 2016;2016:8173182.

128. Fernando MA, Heaney AP. Alpha1-adrenergic receptor antagonists: novel therapy for pituitary adenomas. Mol Endocrinol. 2005;19(12):3085-96.

129. Fukuoka H, Cooper O, Ben-Shlomo A, Mamelak A, Ren SG, Bruyette D, et al. EGFR as a therapeutic target for human, canine, and mouse ACTH-secreting pituitary adenomas. J Clin Invest. 2011;121(12):4712-21.

130. Calhoun DA, White WB, Krum H, Guo W, Bermann G, Trapani A, et al. Effects of a novel aldosterone synthase inhibitor for treatment of primary hypertension: results of a randomized, doubleblind, placebo- and active-controlled phase 2 trial. Circulation. 2011;124(18):1945-55.

131. Fleseriu M, Pivonello R, Young J, Hamrahian AH, Molitch ME, Shimizu C, et al. Osilodrostat, a potent oral $11 \beta$-hydroxylase inhibitor: 22-week, prospective, Phase II study in Cushing's disease. Pituitary. 2016;19(2):138-48.

132. Ideyama $Y$, Kudoh $M$, Tanimoto $K$, Susaki $Y$, Nanya $T$, Nakahara $T$, et al. YM116, 2-(1H-imidazol-4-ylmethyl)-9H-carbazole, decreases adrenal androgen synthesis by inhibiting C17-20 lyase activity in $\mathrm{NCl}-\mathrm{H} 295$ human adrenocortical carcinoma cells. Jpn J Pharmacol. 1999;79(2):213-20.

133. Vance ML. Cushing's disease: radiation therapy. Pituitary. 2009;12(1):11-4.

134. Tritos NA, Biller BM. Update on radiation therapy in patients with Cushing's disease. Pituitary. 2015;18(2):263-8.
135. Jennings AS, Liddle GW, Orth DN. Results of treating childhood Cushing's disease with pituitary irradiation. N Engl J Med. 1977;297(18):957-62.

136. Losa M, Picozzi P, Redaelli MG, Laurenzi A, Mortini P. Pituitary radiotherapy for Cushing's disease. Neuroendocrinology. 2010;92 Suppl 1:107-10.

137. Jagannathan J, Sheehan JP, Jane JA Jr. Evaluation and management of Cushing syndrome in cases of negative sellar magnetic resonance imaging. Neurosurg Focus. 2007;23(3):E3.

138. Sheehan JP, Jagannathan J, Pouratian N, Steiner L. Stereotactic radiosurgery for pituitary adenomas: a review of the literature and our experience. Front Horm Res. 2006;34:185-205.

139. Brada M, Ford D, Ashley S, Bliss JM, Crowley S, Mason M, et al. Risk of second brain tumour after conservative surgery and radiotherapy for pituitary adenoma. BMJ. 1992;304(6838):1343-6.

140. Laws ER, Sheehan JP, Sheehan JM, Jagnathan J, Jane JA Jr, Oskouian R. Stereotactic radiosurgery for pituitary adenomas: a review of the literature. J Neurooncol. 2004;69(1-3):257-72.

141. Smith PW, Turza KC, Carter CO, Vance ML, Laws ER, Hanks JB. Bilateral adrenalectomy for refractory Cushing disease: a safe and definitive therapy. J Am Coll Surg. 2009;208(6):1059-64.

142. Nagesser SK, van Seters AP, Kievit J, Hermans J, van Dulken $\mathrm{H}$, Krans HM, et al. Treatment of pituitary-dependent Cushing's syndrome: long-term results of unilateral adrenalectomy followed by external pituitary irradiation compared to transsphenoidal pituitary surgery. Clin Endocrinol (Oxf). 2000;52(4):427-35.

143. Alberda WJ, van Eijck CH, Feelders RA, Kazemier G, de Herder WW, Burger JW. Endoscopic bilateral adrenalectomy in patients with ectopic Cushing's syndrome. Surg Endosc. 2012;26(4):1140-5.

144. Assié G, Bahurel H, Coste J, Silvera S, Kujas M, Dugué MA, et al. Corticotroph tumor progression after adrenalectomy in Cushing's Disease: A reappraisal of Nelson's Syndrome. J Clin Endocrinol Metab. 2007;92(1):172-9.

145. Ritzel K, Beuschlein F, Mickisch A, Osswald A, Schneider HJ, Schopohl J, et al. Clinical review: Outcome of bilateral adrenalectomy in Cushing's syndrome: a systematic review. J Clin Endocrinol Metab. 2013;98(10):3939-48.

146. Moreira AC, Castro M, Machado HR. Longitudinal evaluation of adrenocorticotrophin and beta-lipotrophin plasma levels following bilateral adrenalectomy in patients with Cushing's disease. Clin Endocrinol (Oxf). 1993;39(1):91-6.

147. Lindsay JR, Jonklaas J, Oldfield EH, Nieman LK. Cushing's syndrome during pregnancy: personal experience and review of the literature. J Clin Endocrinol Metab. 2005;90(5):3077-83.

148. Lindsay JR, Nieman LK. The hypothalamic-pituitary-adrenal axis in pregnancy: challenges in disease detection and treatment. Endocr Rev. 2005;26(6):775-99.

149. Bronstein MD, Machado MC, Fragoso MC. MANAGEMENT OF ENDOCRINE DISEASE: Management of pregnant patients with Cushing's syndrome. Eur J Endocrinol. 2015;173(2):R85-91.

150. Bronstein MD, Paraiba DB, Jallad RS. Management of pituitary tumors in pregnancy. Nat Rev Endocrinol. 2011;7(5):301-10.

151. Woo I, Ehsanipoor RM. Cabergoline therapy for Cushing disease throughout pregnancy. Obstet Gynecol. 2013;122(2 Pt 2):485-7. 